PNL-6565

UC-245

$1 x+H$

\title{
Evaluation of Manure as a Feedstock for Gas Turbines
}

J. T. Hamrick

May 1988

Prepared by Aerospace Research Corporation for Pacific Northwest Laboratory under Contract DE-AC06-76RLO 1830 with the U.S. Department of Energy

Pacific Northwest Laboratory Operated for the U.S. Department of Energy by Battelle Memorial Institute 


\title{
DISCLAIMER
}

This report was prepared as an account of work sponsored by an agency of the United States Government. Neither the United States Government nor any agency thereof, nor Battelle Memorial Institute, nor any or their employees, makes any warranty, expressed or implied, or assumes any legal liability or responsibility for the accuracy, completeness, or usefulness of any information, apparatus, product, or process disclosed, or represents that its use would not infringe privately owned rights. Reference herein to any specific commercial product, process, or service by trade name, trademark, manufacturer, or otherwise does not necessarily constitute or imply its endorsement, recommendation, or favoring by the United States Government or any agency thereof, or Battefle Memorial Institute. The views and opinions of authors expressed herein do not necessarify state or reflect those of the United States Government or any agency thereof, or Battelie Memorial Institute.

\author{
PACIFIC NORTHWEST LABORATORY \\ operated by \\ BATTELLE MEMORIAL INSTITUTE \\ for the \\ UNITED STATES DEPARTMENT OF ENERGY \\ under Contract DE-AC06-76RLO 1830
}

\begin{tabular}{|c|c|}
\hline \multicolumn{2}{|c|}{ Printed in the United States of America } \\
\hline \multicolumn{2}{|c|}{$\begin{array}{c}\text { Available from } \\
\text { National Technical Information Service }\end{array}$} \\
\hline \multirow{3}{*}{\multicolumn{2}{|c|}{$\begin{array}{c}\text { National Technical Information Service } \\
\text { United States Department af Commerce } \\
5285 \text { Port Royal Road } \\
\text { Springfield, Virginia } 2216 \top\end{array}$}} \\
\hline & \\
\hline & \\
\hline \multirow{2}{*}{\multicolumn{2}{|c|}{$\begin{array}{l}\text { NTIS Price Codes } \\
\text { Microfiche A01 }\end{array}$}} \\
\hline & \\
\hline \multicolumn{2}{|c|}{ Printed Copy } \\
\hline & Price \\
\hline Pages & Codes \\
\hline $001-025$ & $\mathrm{~A} 02$ \\
\hline $026-050$ & $\mathrm{~A} 03$ \\
\hline $051-075$ & $\mathrm{AO4}$ \\
\hline $076-100$ & $\mathrm{~A} 05$ \\
\hline 101.125 & $A 06$ \\
\hline $126-150$ & $\mathrm{~A} 07$ \\
\hline $151-175$ & AOS \\
\hline $176-200$ & $A 09$ \\
\hline $20 \uparrow-225$ & A010 \\
\hline $226-250$ & A071 \\
\hline $251-275$ & A012 \\
\hline $276-300$ & $A 013$ \\
\hline
\end{tabular}


PNL -6565

UC -245

EVALUATION OF MANURE

AS A FEEDSTOCK FOR

GAS TURBINES

J. T. Hamrick

Aerospace Research Corporation

Roanoke, Virginia 24014

May 1988

Prepared by Aerospace Research Corporation for Pacific Northwest Laboratory under Contract DE-AC06-76RLO 1830 with the U.S. Department of Energy

Pacific Northwest Laboratory

Richland, Washington 99352 


\section{EVALUATION OF MANURE AS A FEEDSTOCK FOR GAS TURBINES}

\section{EXECUT IVE SUMMARY}

Large quantities of manure are generated in several areas of the United States where cattle are conditioned in feedlots prior to slaughter. Results of a survey published by the Stanford Research Institute show that on the order of 3.24 billion kw hrs of electricity can be generated annually with manure now being wasted, enough to supply 260 three megawatt gas turbine systems operating during peak demand periods. With combined wasted and returned manure, on the order of 1,300 systems can be supplied under the same conditions.

Mr. Fred Sparber of New Mexico, who has been working for many years on methods of converting feed lot manure into usable energy, learned of the research that was being conducted by Aerospace Research Corporation on wood fired gas turbines and visited the experimental facility. Through his efforts, those of Mr. Hoyt Pattison of New Mexico, and others a research effort was funded to determine if manure could be burned in the small wood burning gas turbine facility. Efforts started with analysis of the manure. One major difference between manure and sawdust lies with the ash content. The natural ash in manure is on the order of 18 percent as compared with 1 to 2 percent for wood. In the process of collecting the manure, however, a large amount of sand and soil is scraped up, raising the ash content to approximately 25 percent. All of the gaseous combustion products from the manure which is burned under pressure pass through the turbine and must be cleaned of ash in cyclone filters before reaching the turbine. The effects of the ash on the burning process as well as the cleaning problem were unknown and were considered to be major points of investigation. In addition, manure contains chloride salts that are not present in wood and which could cause corrosion of the turbine blades.

In the research that was carried out with manure in the small gas turbine facility there was no evidence that combustion of the manure was adversely affected by the ash and removal of the ash was easily effected by the cyclones. Pulverizing and feeding of the manure gave rise to no major problems. The only immediate problem involved slag from melting of ash on the refractory walis of the combustion chamber, a problem that did not occur with wood. The Australians encountered a similar problem in burning coal in a refractory lined chamber. They solved the problem by designing an all metal combustor for which the walls were cooled below the melting point of the ash by air from the compressor. A similar approach can be taken with manure.

Aside from the possible corrosion problem which will require thousands of running hours to assess, the combustor slagging problem appears to be the primary road block to designing a $3000 \mathrm{kw}$ system similar to the one now in operation on wood. 
It has been determined that for the present, based on research with wood, the gas turbine inlet temperature will have to remain at or below $1450^{\circ} \mathrm{F}$ to avoid excessive fouling of the blades, and that water or steam augmentation will be necessary to produce $3000 \mathrm{kw}$ with the gas turbine now in use. Steam generated with the turbine exhaust gases will not only increase power but also efficiency.

Operation with manure in the small gas turbine facility did not appear significantly different from wood, the slagging of the refractory walls being the major difference. The exhaust varied from clear to a blue haze. With wood it is continually clear. Blade corrosion could prove to be a problem but one that may be solved by use of appropriate blade coatings, should it occur. An alternative solution is to wash the corrosive salts from the manure.

In sunmary, the research on manure as a fuel for gas turbines has shown that there is realistic potential for conversion of manure to usable electrical energy with gas turbines. The combustion chamber that was developed for wood combustion is not suitable for manure due to slag accumulation on the refractory walls. There are parts of the process that can be improved such as manure drying methods, fuel preparation, and possibly direct injection of manure-water slurries into the combustor. However, the one major effort that is needed for design of a large system for comercial application is the development of a suitable combustion chamber. 
TABLE OF CONTENTS

INTROOUCTION

Page

APPARATUS AND INSTRUMENTATION

APPARATUS $\quad 2$

INSTRUMENTATION

CHARACTERIZATION OF MANURE AS A FUEL

CHEMICAL ANALYSIS

HIGHER HEATING VALUE

ASH FUSION TEMPERATURE

MANURE HANOLING

ESTIMATED PARTICULATE LOADING OF GASES TO TURBINE

LOADING OF $\mathrm{S}, \mathrm{Na}, \mathrm{K}$, AND Cl IN THE FLUE GAS AND EFFECT ON ANTICIPATED LIFE

THEORETICAL ANALYSES.

BACKGROUND INFORMATION

EXPERIMENTAL RESULTS

EMISSION MEASUREMENTS

DISCUSSION OF RESULTS

RECOMMENDED FURTHER RESEARCH AND DEVELOPMENT 16

$\begin{array}{ll}\text { DEVELOPMENT OF A SUITABLE COMBUSTOR } & 16\end{array}$

LONG TERM OPERATION

$\begin{array}{ll}\text { FUEL PREPARATION } & 17\end{array}$

Separation of Sand and Rock 17

$\begin{array}{ll}\text { Orying of Manure } & 17\end{array}$

$\begin{array}{ll}\text { Manure-Water Slurries } & 17\end{array}$

$\begin{array}{ll}\text { SUMMARY OF RESULTS } & 18\end{array}$ 


$$
\text { CONTENTS - CONTINUED }
$$

APPENDIX 1 - REFERENCES

APPENDIX 2 - CHEMICAL ANALYSES DF FEEDLOT MANURE FROM CLOVIS, NEW MEXICO

APPENDIX 3 - SEPARATION OF ROCK AND SAND FROM DRY FEEDLOT MANURE

APPENDIX 4 - THEORETICAL PERFORMANCE OF THE ALLISON T-56-15

GAS TURB INE WITH AND WITHOUT WATER/STEAM INJECTION 


\title{
EVALUATION OF MANURE AS A FEEDSTOCK FOR GAS TURB INES
}

\author{
Joseph T. Hamrick \\ Aerospace Research Corporation \\ 5454 JAE Valley Road \\ Roanoke, Virginia 24014
}

\begin{abstract}
A preliminary program on evaluation of feedlot manure as a feed stock for gas turbines has been completed. It was determined that manure can be pulverized and fed into a gas turbine combustion system with the manure burning in much the same manner as a liquid or gaseous fuel. Ash and dirt in the manure did not appear to have a significant effect on combustion and were effectively removed by the cyclone filters. The exhaust gases varied from clear to a blue haze. Severe problems were encountered with slagging of the hot refractory walls of the combustor. Development of a suitable combustor will be required before a commercial size system can be designed.
\end{abstract}

\section{INTRODUCT ION}

Large quantities of manure are generated in several areas of the United States where cattle are conditioned in feedlots prior to slaughter. Results of a survey published by the Stanford Research Institute (Table 1)(1)* show that on the order of 3.24 billion $\mathrm{kw}$ hrs of electricity can be generated annualiy with manure now being wasted, enough to supply 260 three megawatt gas turbine systems operating during peak demand periods. With combined wasted and returned manure, on the order of 1,300 systems can be supplied under the same conditions. Based on this information, direct combustion tests of manure in a gas turbine was proposed using as a research vehicle the system that was previously used for direct combustion of wood $(2,3,4,5$, 6). The proposed program was funded to cover preliminary testing of manure in that system.

It was determined that preparation, feeding, combustion, and ash removal can be accomplished with the prototype system used with wood. A major difference in performance was experienced in the combustion chamber where slagging occurred on the refractory lining of the chamber. A minor difference occurred in the visibility of exhaust emissions. Whereas the exhaust from wood is clear the exhaust from manure varied from clear to a blue haze.

It is the purpose of this report to describe the apparatus and instrumentation, to characterize manure as a fuel, and to present the results of the investigation. Also included are theoretical analyses and a discussion of the needed future areas of investigation. The combustion chamber used in the investigation was designed for wood. After passing through a pulverizer, manure particles are much finer than the wood particles for which

*Numbers in parentheses refer to references in Appendix 1 . 
the combustion chamber was designed. As a result, a greater quantity of manure particles are centrifuged out against the walls of the combustor where they burn and heat the walls above the melting point of the ash, producing a slagging problem. It is recommended that a combustion chamber designed exclusively for manure be evaluated and developed. In addition, the injection and combustion of manure-water slurries should be investigated.

TABLE I TOTAL MANURE RESIDUE DISPOSITION--CONTERMINOUS U.S. (FROM CROP, FORESTRY, AND MANURE RESIDUE INVENTORY - CONTINENTAL U.S. VOL I BY STANFORD RESEARCH INSTITUTE, JUNE 1976)

Tons-Dry Weight

\begin{tabular}{|c|c|c|c|c|c|c|}
\hline & Sold & Fed & Fuel & Returned & Wasted & Total \\
\hline anure & $3,920,283$ & 247,064 & 16,436 & $17,845,698$ & $4,429,867$ & $26,459,348$ \\
\hline $\begin{array}{l}\text { ercent } \\
\text { fotal Total }\end{array}$ & 12.3 & 12.2 & 4.9 & 52.1 & 18.5 & $100.0 \%$ \\
\hline
\end{tabular}

The utilization categories shown in the table are defined as follows:

Sold--that portion of available residues that is collected and sold for any purpose.

Fed--that portion of available residues that is fed to animals without collection or with collection but without sale.

Fuel--that portion of available residues that is used as fuel without sale.

Returned--that portion of the available manure residues that is returned to the soil without sale.

Wasted--that portion of the available residues that must be disposed of at an economic cost (i.e., they are returned to the soil at an economic cost).

\section{APPARATUS AND INSTRUMENTATION}

\section{APPARATUS}

A schematic of the system is shown in figure 1. Dried manure is fed into the hammermill with a half inch screen where it is pulverized to a $.01 \mathrm{~mm}$ or less particle size before being pneumatically transported to the feed bin. It is then metered from the bottom of the feed bin into the rotary valve feeders that move it from ambient pressure in the feed bin into the pressurized combustor. The compressor supplies both combustion air and excess of air for cooling. The ash laden combustion products move through two cyclones in series where the ash is removed before entry of the hot 


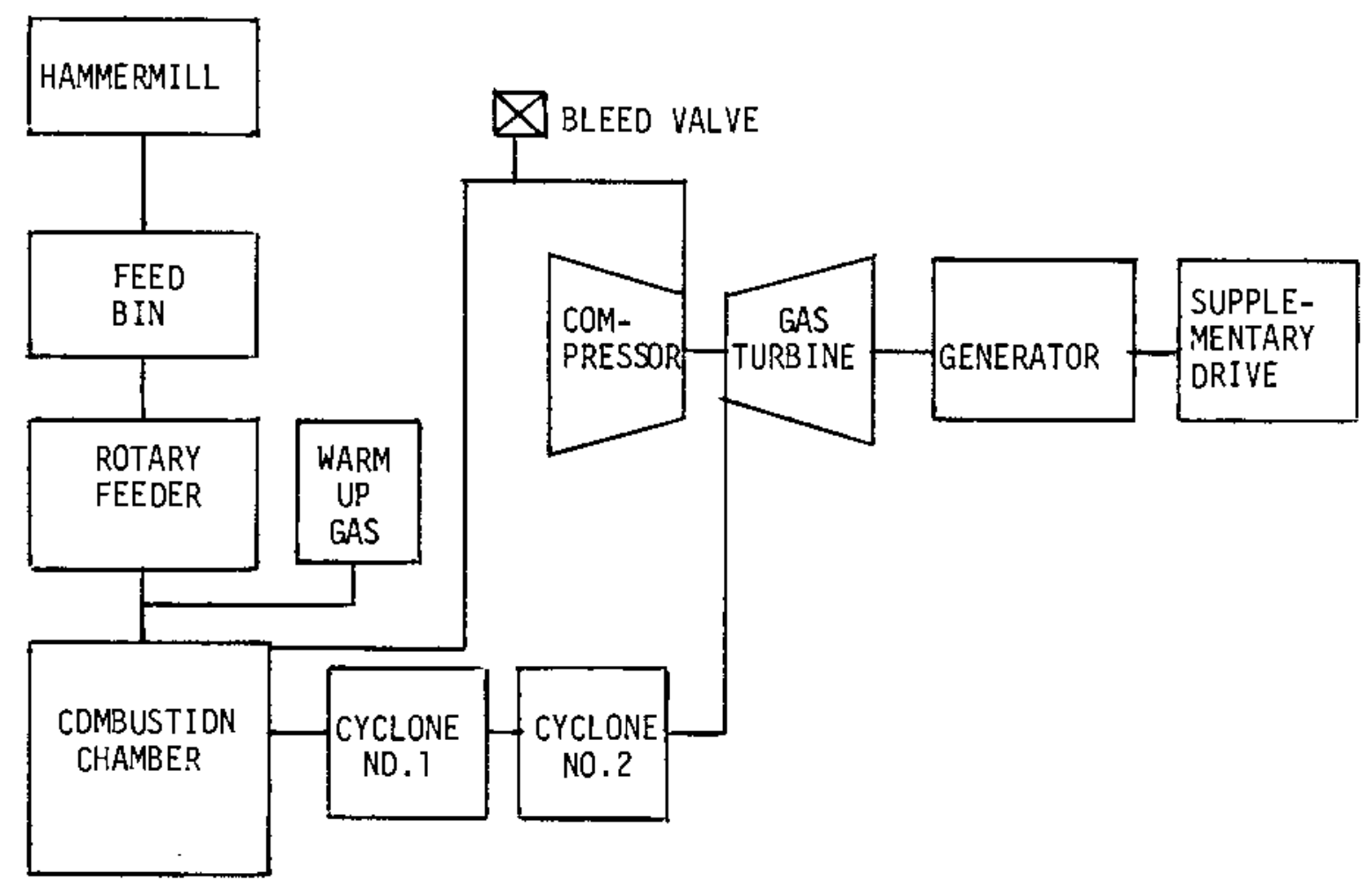

FIGURE 1. Schematic of Gas Turbine System

gases into the turbine. The turbine drives the compressor. The gas turbine used in the system, manufactured by the Garrett Corporation, is designated mode1 GTP 831-200. It was designed to operate on dieseT fuel. In modifying the combustor section to include a large wood burning chamber and cyclone filters the pressure drop between the compressor outlet and turbine intet was increased from the normal 4 percent of compressor outlet absolute pressure to approximately 7 percent, thereby decreasing the surge margin of the compressor. Surge is characterized by a highly audible, sharp sounding noise caused by aerodynamic instability as the compressor reaches its maximum pressure at a given speed. The two stage centrifugal compressor in the Garrett engine has a much smaller differential between operating pressure and maximum pressure than the fourteen stage axial flow compressor in the Allison T-56 engine currently in use with wood. To reduce the tendency for the compressor to surge as speed is increased air can be bled off between the compressor and combustion chamber. The bleed valve position is shown in figure 1 . Because of the narrowed surge margin it was not possible to raise the engine speed to the rated $41,730 \mathrm{rpm}$. The amount of air bleed required to attain that speed is such that the supplementary drive does not have adequate power to make up the loss incurred in bleeding. At 25,000 rpm the surge margin is adequate for operation without air bieed, but input from 
the supplementary drive is necessary. At 25,000 rpm the temperature of the air at the compressor outlet is only $370^{\circ} \mathrm{F}$ as compared to the approximate 650 of that is reached at $41,730 \mathrm{rpm}$. As a result, it was necessary to inject approximately 5 percent propane (Btu basis) with both wood and manure to insure stable combustion.

Views of the experimental apparatus are shown in figures 2 through 5. A schematic of the burner arrangement is shown in figure 6 .

One difference in the feed system between wood and manure is that the manure is moved pneumatically from the hammermill to the feed bin whereas wood was moved by flexible auger. The system is brought up to speed initially by a 24 volt battery powered starter. Speed is then sustained by the supplementary drive which consists of a 60 horsepower electric motor, a variable speed belt drive, and a sprag clutch. Upon reaching approximately 17,000 rpm engine speed propane gas is injected into the combustor to warm up the system. Upon reaching a sustained turbine exhaust gas temperature of $500 \% \mathrm{~F}$, the manure feed is started and the system speed increased to $21,000 \mathrm{rpm}$. The gas feed is decreased and the manure feed increased until a minimum of gas is required. Based upon experience with wood at high turbine speeds the temperature of the air combined with the high pressure will make for intense combustion so that no gas supplement will be necessary.

\section{INSTRUMENTATION}

Temperatures were measured by means of chromel-alumel thermocouples. The primary points of measurement were of compressor air, at the combustor inlet, combustion products at the combustor outlet, hot gas temperature at the first cyclone wall, hot gases entering the turbine, and turbine exhaust. Pressures were measured at the compressor outlet and turbine inlet. A pressure differential gage was used to measure directly the pressure loss from compressor outlet to turbine inlet. Manure feed was controlled by a variable speed drive operated from the control room. Engine speed was read out on a digital counter.

\section{CHARACTERIZATION OF MANURE AS A FUEL}

As manure has been used as a fuel for centuries, there was little doubt as to its combustibility. The primary concerns with its use in a gas turbine were the number of cyclone stages needed for ash disposal, slag formation, and corrosiveness of the combustion products. It has al ready been demonstrated with coal research that ash particles large enough to erode the turbine could be removed with cyclone filters (7). The first step was to obtain analyses of manure samples. Feedlot manure samples furnished by Mssrs. Hoyt Pattison and Fred Sparber from Clovis, New Mexico were analyzed.

\section{CHEMICAL ANALYSIS}

The results of chemical analyses of the manure by Froehling and Robertson and Centec Analytical Services are included in Appendix 2. A ten per- 


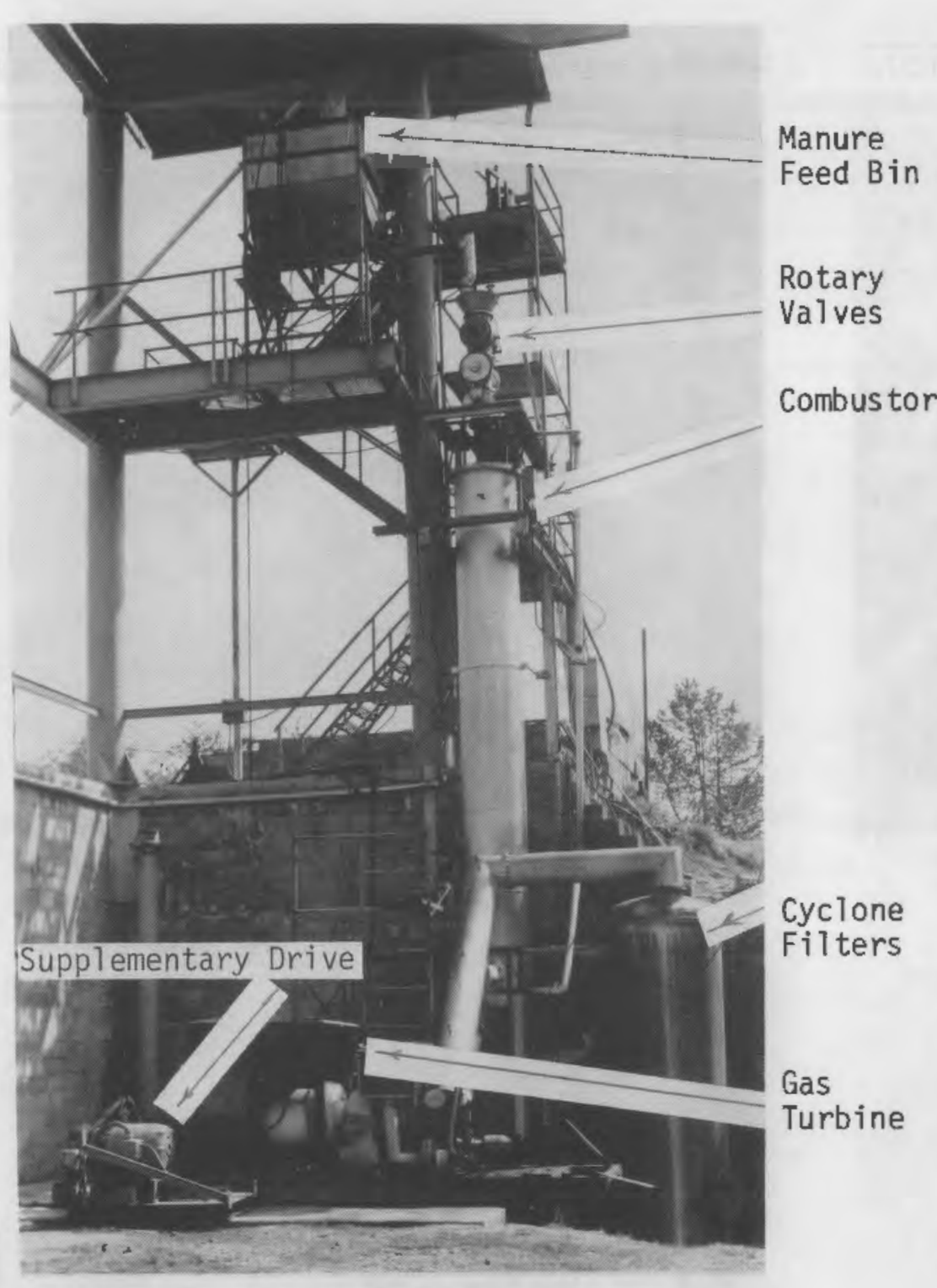

FIGURE 2. Side View of Gas Turbine ana Wood Combustion System.

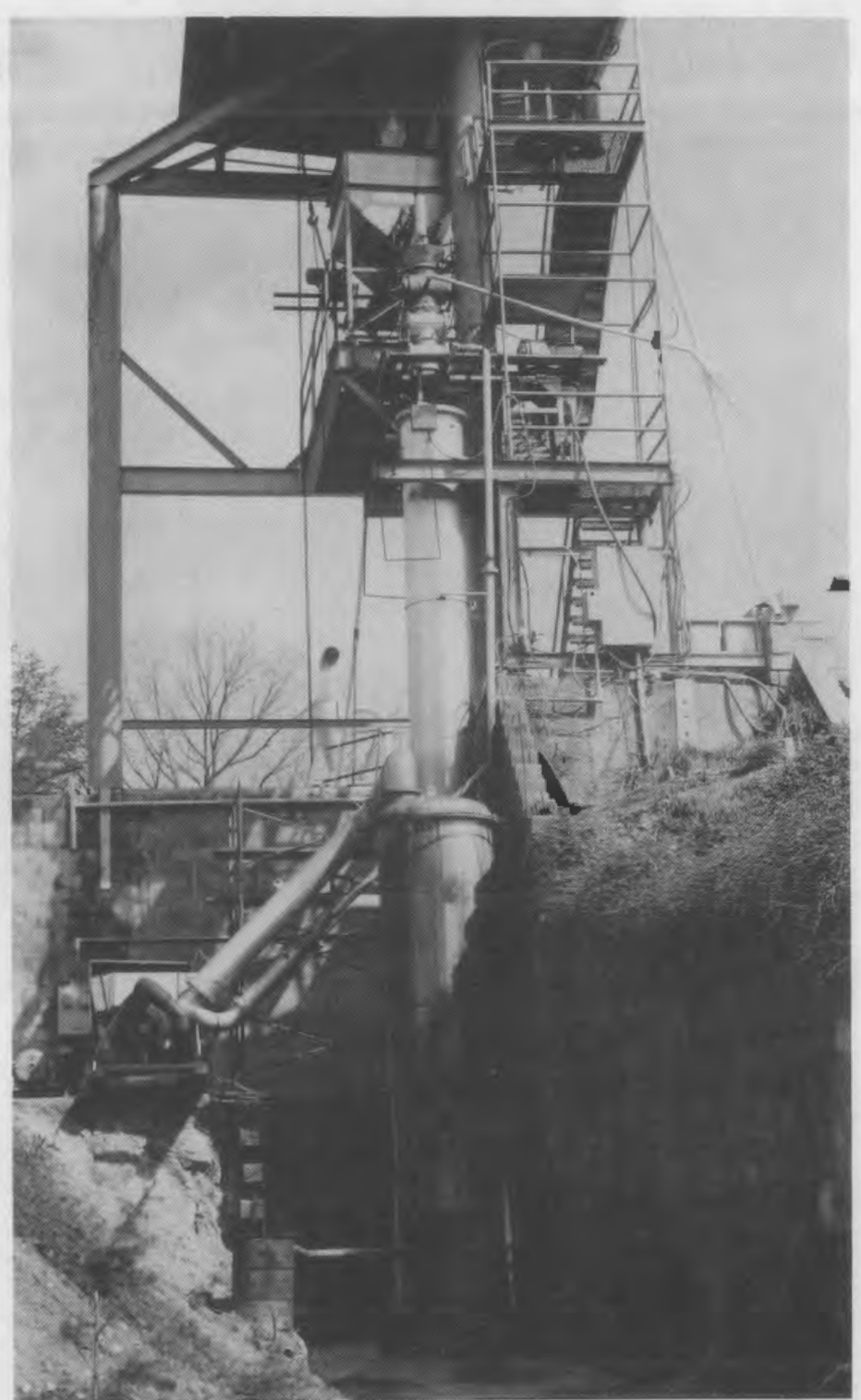

FIGURE 3. Exhaust End View of Gas Turbine and Wood Combustion System. 


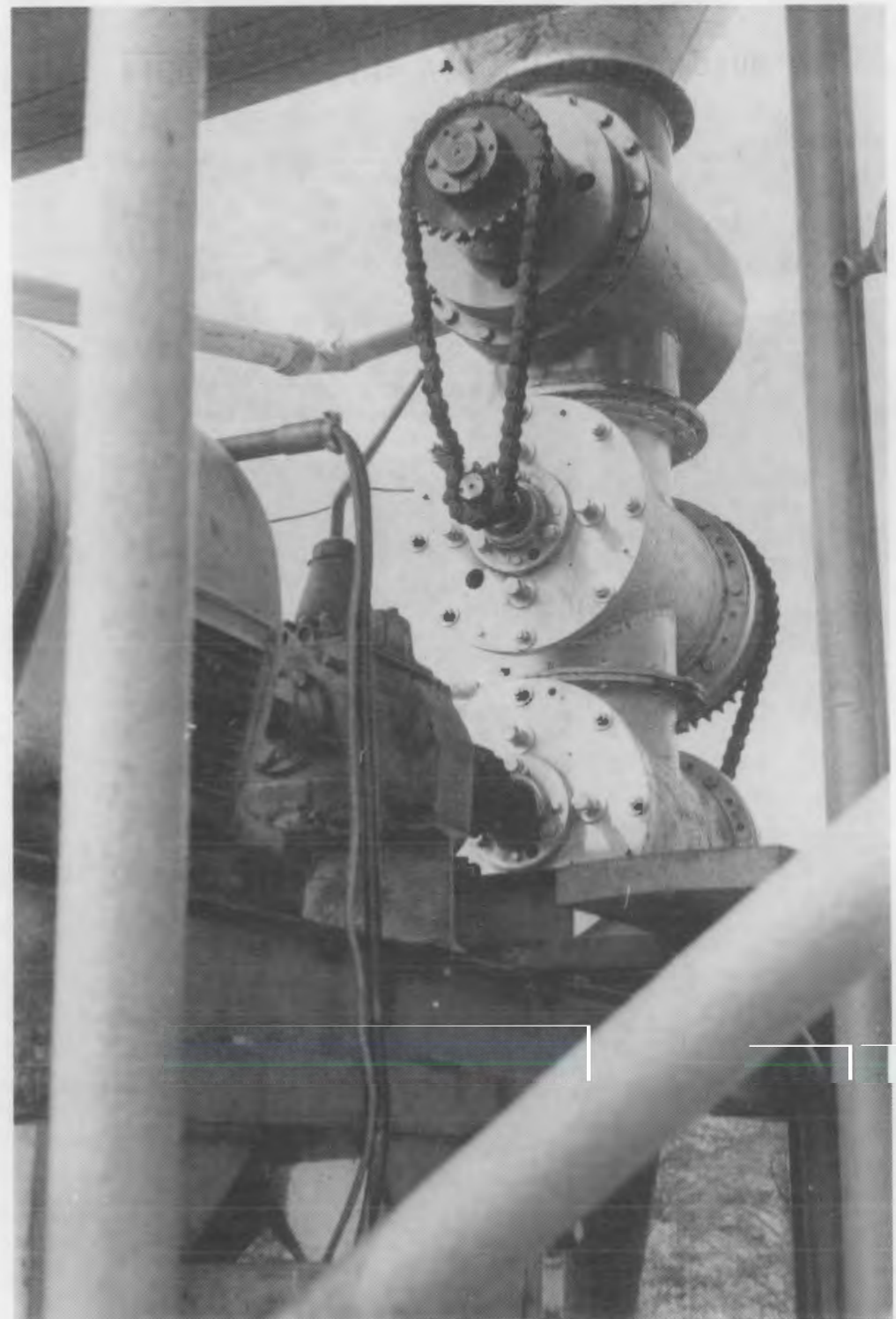

FIGURE 4. Closeup View of Rotary Valve Feeders

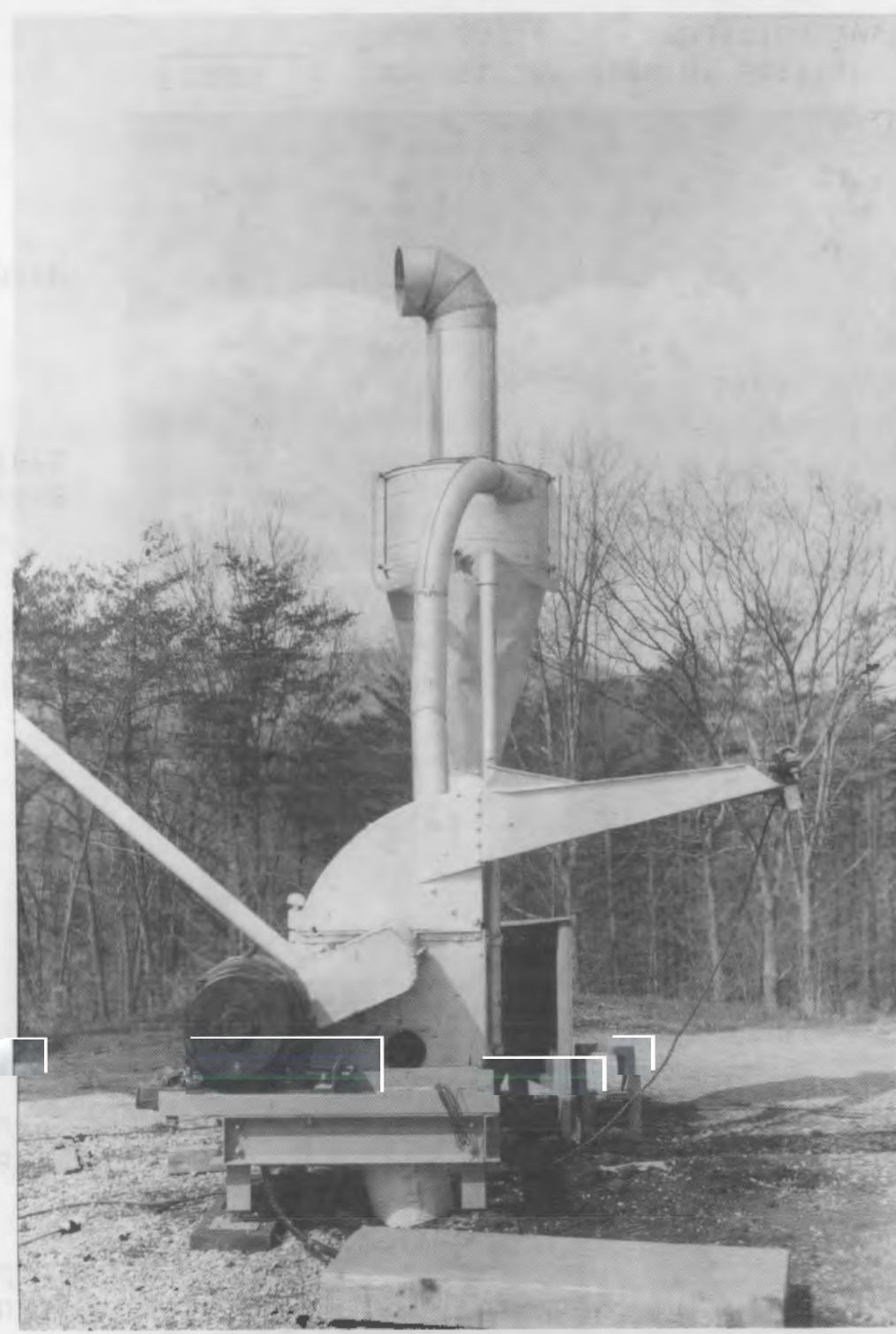

FIGURE 5. View of Manure Pulverizer. Tube at Left Delivers Manure Pneumatically to Manure Feed Bin (Fig 2) 


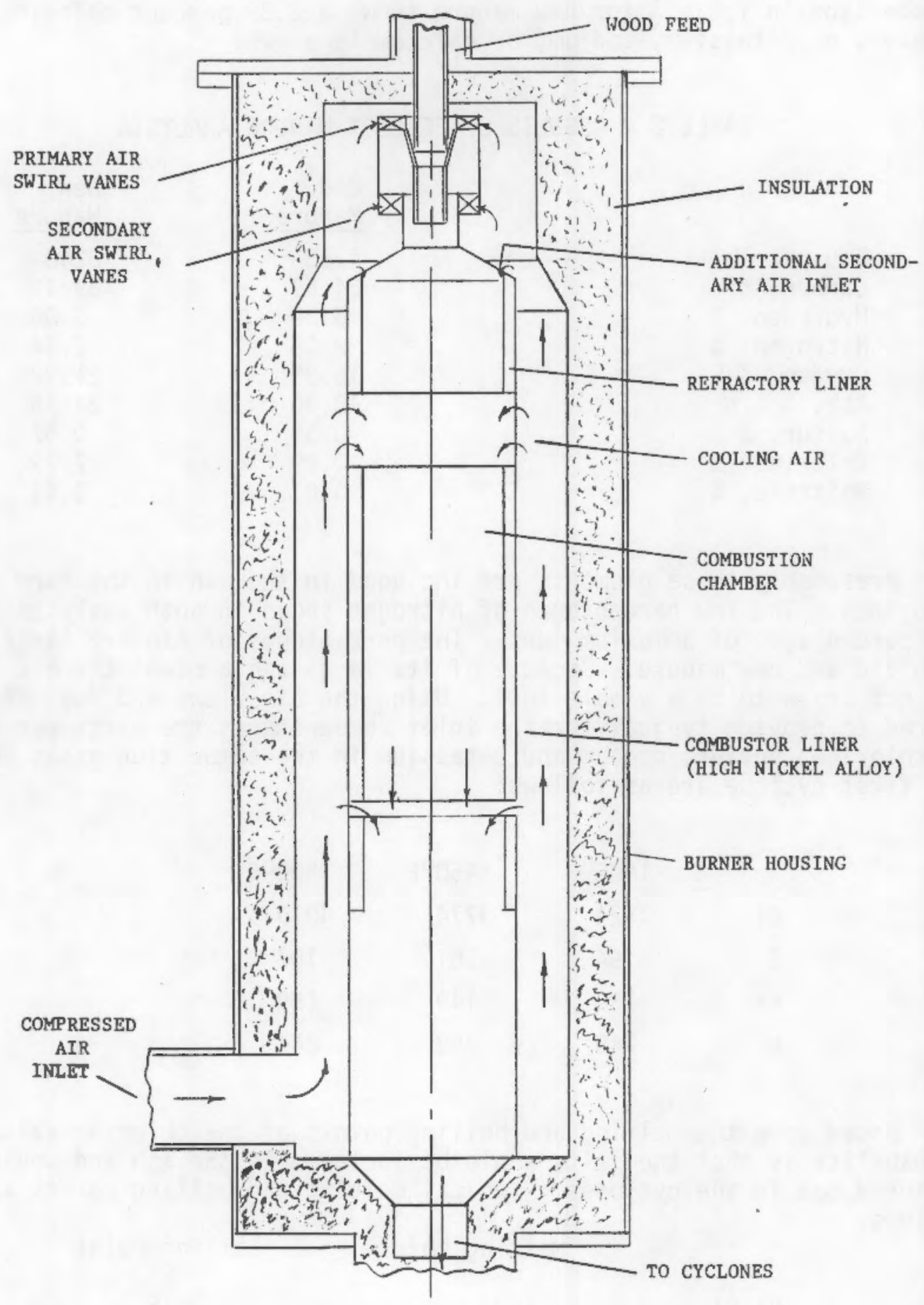

FIGURE 6. Schematic of Burner Arrangement 
cent loading of chloride ions is shown in the Centec Analysis. It is difficult to reconcile the large amount of chlorides shown in the analysis with the positive ions that are listed. The ultimate analysis from Froehling $\&$ Robertson in Table 2 for new manure shows a 2.39 percent chlorine content. However, no potassium, sodium, or calcium is shown.

\section{TABLE 2 - RESULTS OF FEEDLOT MANURE ANALYSIS}

\begin{tabular}{llc} 
& $\begin{array}{l}\text { Old } \\
\text { Manure }\end{array}$ & $\begin{array}{l}\text { New } \\
\text { Manure }\end{array}$ \\
\cline { 2 - 3 } Btu per 1b. & 4263 & 6240 \\
Carbon, \% & 24.67 & 39.43 \\
Hydrogen, \% & 3.39 & 5.05 \\
Nitrogen, \% & 2.18 & 2.34 \\
Oxygen, \% & 16.35 & 21.92 \\
Ash, \% & 48.96 & 24.76 \\
Sulfur, \% & 0.55 & 0.67 \\
Chlorine, \% & 0.29 & 2.39 \\
Moisture, \% & 3.61 & 3.44
\end{tabular}

Presumably these elements are included in the ash in the form of chlorides. The low percentages of nitrogen shown in both analyses indicate low percentages of ammonium ions. The percentages of ash are large for both old and new manure. Because of its large ash content the old manure may not prove to be a viable fuel. Using the air flows and fuel feed required to provide typicá? turbine inlet temperatures the parts per million of chloride, sulfur, sodium and potassium in the combustion gases entering the first cyclone are as follows:

$\begin{array}{lrrr} & 1400^{\circ} \mathrm{F} & 1450^{\circ} \mathrm{F} & 1500^{\circ} \mathrm{F} \\ \mathrm{Cl} & 3524 & 3774 & 4019 \\ \mathrm{~S} & 94 & 101 & 107 \\ \mathrm{Na} & 139 & 149 & 159 \\ \mathrm{~K} & 740 & 792 & 844\end{array}$

Based upon the melting and boiling points of the chlorine salts the probability is that the salts would be included in the ash and would be filtered out in the cyclones. Typical melting and boiling points are as follows:

$\begin{array}{cc}\text { Melting Point } & \text { Boiling Point } \\ \text { of } & \text { of } \\ 1473 & 2575 \\ 1421 & >2912 \\ 1429 & \text { Sublimates } 2732\end{array}$


It is difficult to predict on the basis of chemical analyses what quantities of any chemical will reach the turbine.

HIGHER HEATING VALUE

The higher heating values of two samples of feed lot manure as determined by Froehling and Robertson are shown in table 2. The old manure, with 48.96 percent ash, had a higher heating value of $4263 \mathrm{Btu} / 1 \mathrm{~b}$. The new manure, with 24.76 percent ash, had a higher heating value of 6240 Btu/1b. Eliminating the ash and basing the heating value on the combustibles only, the higher heating value of the old manure is $8352 \mathrm{Btu} / 1 \mathrm{~b}$ and that for the new manure is $8293 \mathrm{Btu} / 1 \mathrm{~b}$. These values are very close to those for biomass with low ash content.

\section{ASH FUSION TEMPERATURE}

The ash fusion and melting temperatures are important from standpoints of blade deposition and collection of slag in the combustor. Determination of ash fusion temperature, of necessity, involves visual judgement and possibly instrument error. To make a preliminary determination of the effects of temperature, ash from the manure was heated in a crucible while being stirred with a $1 / 8 \mathrm{in}$. dia. shielded thermocouple probe.

The ash behaved upon heating as follows:

\begin{tabular}{|c|c|c|c|c|c|}
\hline \multirow[b]{2}{*}{$\begin{array}{l}\text { Sample } \\
\text { No. }\end{array}$} & \multicolumn{5}{|c|}{ Temperature Effect } \\
\hline & $\begin{array}{l}\text { 8ecame } \\
\text { Tacky of }\end{array}$ & $\begin{array}{l}\text { Started } \\
\text { To Lump }\end{array}$ & OF & $\begin{array}{l}\text { Putty } \\
\text { Consistency of }\end{array}$ & $\begin{array}{l}\text { Began to } \\
\text { Flow of }\end{array}$ \\
\hline 1 & 1688 & - & & 1763 & 2038 \\
\hline 2 & 1526 & 1880 & & - & 1950 \\
\hline 3 & 1570 & 1687 & & 1943 & 2303 \\
\hline
\end{tabular}

It can be seen that of the three samples none reacted the same. However, the manure ash appears to become tacky at a higher temperature than oak wood ash which becomes tacky around $1450^{\circ} \mathrm{F}$. It did not appear that the ash from manure would react much differently than ash from wood in the gas turbine system.

\section{MANURE HANDLING}

Manure as received from New Mexico was fed through the hammer mill with no difficulty. Only minor difficulty was encountered in conveying the milled material to the feed bin and through the rotary valves. Rocks in the manure caused a problem. Most of the rocks were removed in the transfer of manure from the pulverizer to the pneumatic conveying tube. However, pea size rocks would occasionally get through to the wood bin metering auger and cause it to jam. A study of the rock and sand separation problem was made. The results are presented in Appendix 3. 


\section{ESTIMATED PARTICULATE LOADING OF GASES TO TURBINE}

There are two cyclones in the $375 \mathrm{kw}$ system both of which were designed on the basis of information provided by the Coal Utilisation Research Laboratories (CURL) at Leatherhead, England (7). The performances of the primary and secondary cyclones in stream 1 of the CURL facility are shown in figure 7.

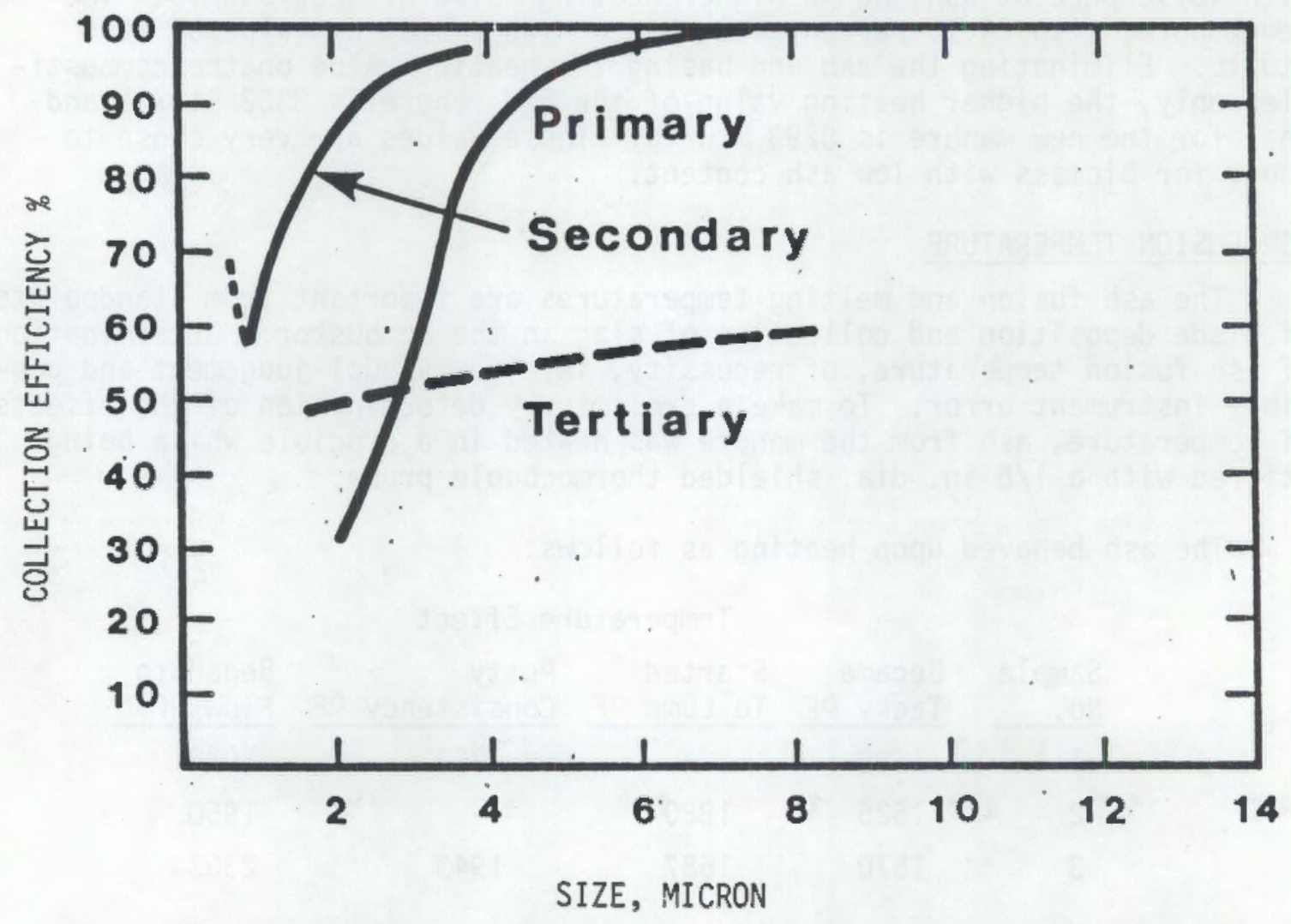

FIGURE 7. Efficiencies of CURL Cyclones

Computed performance for the T-56 gas turbine with manure as the fuel showed $.297 \mathrm{lbs}$ of ash per second for a gas flow of $34.25 \mathrm{lbs} / \mathrm{sec}$ or 8671 parts per million. It was estimated that the first cyclone would remove 95 percent of all particles above 5 microns leaving 433 parts per million of particles below that size and that the second cyclone would take out 94 percent of the particles above 3 microns in size leaving 26 parts per million of particles below that size. On that basis a third cyclone was not considered to be required as the turbine manufacturer stated that particles below 5 microns would not erode the turbine. The curve for the tertiary cyclone in figure 7 is meaningless because of the small population of particles in the stream past the second cyclone. 
LOADING OF S, Na, K, ANO Cl IN THE FLUE GAS AND EFFECT ON ANTICIPATED LIFE

As previously stated, the melting and boiling points of the chlorides is high. Therefore, it was expected that most of them would be removed in the cyclones. However, there is sulfur present, and it may result in excessive sulfidation over a long running period. Advances are being made in turbine blade coatings. If corrosion occurs from either the sulfur or the chlorides it is anticipated that suitable coatings can be found to reduce or eliminate it.

\section{THEORETICAL ANALYSES}

\section{BACKGROUND INFORMATION}

For a number of reasons the General Motors - Allison T-56 gas turbine is the most favorable one for use in a manure burning gas turbine power generation system. As a result it was used as a basis for computing theoretical performance. The reasons for its selection are:

1) It is the only $3000 \mathrm{kw}$ axial flow compressor engine manufactured in the United States that can be easily adapted to a combustor that is offset from the compressor and turbine.

2) The axial flow compressor in the T-56 engine has a wide surge margin that allows use of water/steam augmentation in the combustor.

3) The engine, being an aircraft engine currently in production is widely available, both new and used.

4) The $3000 \mathrm{kw}$ output of the engine is in the range that is compatible with manure supplies available in feed lot areas with economical hauling costs.

5) The turbine section of the engine can be removed and replaced in four hours or less.

The maximum temperature at which blade endurance was tested at the Coal Utilisation Research Laboratory (7) was $1500^{\circ} \mathrm{F}$. It was reported (7) that cooling of the blade surfaces to 1350 to $1450^{\circ} \mathrm{F}$ appeared to be a viable method of reducing corrosion to acceptable rates in pressurized fluidized bed powered turbines. FeCrAIY and COCrAIY alloy coatings on blades offered improved resistance to corrosion (7). While no evidence of corrosion has been detected in operation with wood over hundreds of hours, there is the possibility that contaminants in the exhaust from manure combustion can cause corrosion, making such coatings necessary.

One problem with use of wood as a fuel has been the formation of hard coatings on the turbine blades and inlet stators at turbine inlet temperatures above approximately $1450^{\circ} \mathrm{F}$. The hard deposits appear to be composed of sintered ash powder which collects on the blades. As can be seen from the section on ash fusion temperatures the manure ash becomes visibly tacky 
above $1500^{\circ} \mathrm{F}$. Therefore, it was expected that a deposition and sintering problem similar to that with wood can occur, and that the turbine inlet. temperature probably will have to be restricted to approximately 1450 of unless the problem is resolved.

To derive rated power from the T-56 gas turbine with an average turbine inlet temperature of $1400^{\circ} \mathrm{F}$ requires injection of water or steam into the hot gases during or at the end of the combustion process. Water injection into turbines in Australia (8) was reported by J.C. Wisdom of Australia as early as 1958. Calculations were made to determine power output and efficiency for the T-56-15 gas turbine with and without water or steam. The - 15 model more closely approaches in performance the $501 \mathrm{~KB}$ commercial version of the engine than the T-56 -9 version that is being used in the wood burning program. Computations were made with varying amounts of injected water and steam. The results of the calculations for steam injection are shown in figure 8 for turbine inlet temperatures of 1400,1450 , and $1500^{\circ} \mathrm{F}$. Results are shown for water injection in figure 9. The computer printouts for the theoretical performance shown in figures 8 and 9 are included in Appendix 4. All of the steam that is needed for injection can be generated by routing the exhaust gases through an eighty percent efficient waste heat boiler. Results with steam injection by Allison in the $501 \mathrm{~KB}$ gas turbine and water injection in the $3000 \mathrm{kw}$ wood burning system have proven the effectiveness of the method. As can be seen in figures 8 and 9 , there is substantial improvement in system efficiency with the use of steam as opposed to water.

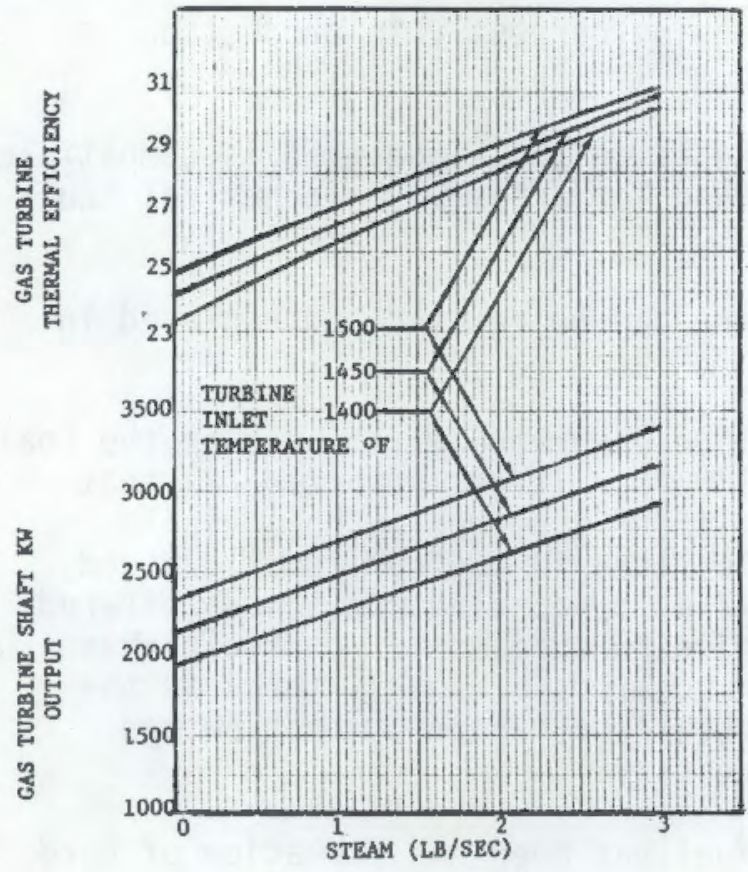

FIGURE 8. T-56-15 Gas Turbine Performance With Steam Injection

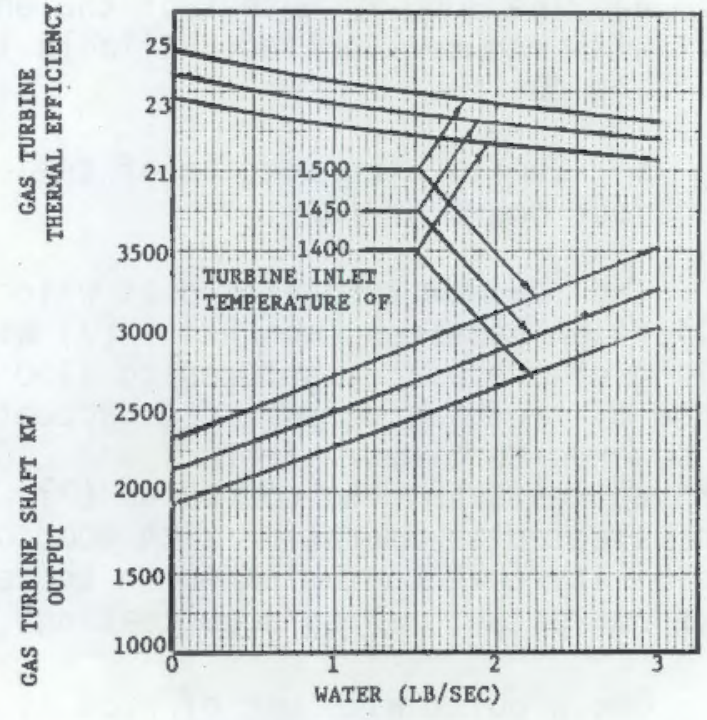

FIGURE 9. T-56-15 Gas Turbine Performance With Water Injection 


\section{EXPERIMENTAL RESULTS}

The system was operated first with wood and then with manure to allow a comparison. Representative results are shown in Table 3 .

TABLE 3 RESULTS FROM OPERATION WITH MANURE AND WOOD

\begin{tabular}{|c|c|c|c|c|c|c|c|c|c|}
\hline \multirow{2}{*}{$\begin{array}{l}\text { MEASUREMENT } \\
\text { LOCATION }\end{array}$} & \multicolumn{8}{|c|}{ MANURE RUN N } & \multirow{2}{*}{ WOOD } \\
\hline & 7 & 2 & 3 & & 5 & $\frac{6}{6}$ & 7 & 8 & \\
\hline Compressor Outlet, ${ }^{\circ} \mathrm{F}$ & 369 & 307 & 310 & 329 & 266 & 261 & 270 & 243 & 306 \\
\hline Ambient Temperature ${ }^{\circ} \mathrm{F}$ & 88 & 87 & 91 & 83 & 63 & 62 & 62 & 29 & - \\
\hline Combustor Outlet, of & 1770 & 1773 & 1714 & 1787 & 1418 & 1453 & 1635 & 1470 & 1642 \\
\hline Top of Cyclone \#1, of & 1740 & 1762 & 1720 & 1749 & 1456 & 1504 & 1649 & 1499 & 1650 \\
\hline Bottom of Cyclone $\# 1$, ${ }^{\circ} \mathrm{F}$ & 1636 & 1587 & 1607 & 1598 & 1451 & 1451 & 1590 & 1420 & 1534 \\
\hline Upper Turbine Inlet, of & 1480 & 1445 & 1448 & 1452 & 1322 & 1330 & 1396 & 1227 & 1409 \\
\hline Mid Turbine Inlet, of & 1491 & 1441 & 1436 & 1432 & 1320 & 1329 & 1422 & 1261 & 1414 \\
\hline Final Turbine Inlet, ${ }^{\circ} \mathrm{F}$ & 1286 & 1201 & 1197 & 1188 & 1200 & 1202 & 1262 & 1122 & 1225 \\
\hline Exhaust Gases, ${ }^{\circ} \mathrm{F}$ & 797 & 742 & 720 & 692 & 703 & 681 & 783 & 626 & 743 \\
\hline Engine Speed, Rpm/1000 & 25.07 & 19.96 & 19.7 & 19.91 & 25.72 & 1997 & 22.17 & 22.36 & 20.61 \\
\hline Compressor Pressure, psig & 19.5 & 11.2 & 11.5 & 12.0 & 14.0 & 12.5 & 13.2 & 13.0 & 12 \\
\hline Combustor Pressure, psig & 18.8 & 10.0 & 10.2 & 10.5 & 12.9 & 11.5 & 12.2 & 12.0 & 11 \\
\hline Turbine Inlet, psig & 17.5 & 9.5 & 9.8 & 10.0 & 12.1 & 11.0 & 11.5 & 11.8 & 10 \\
\hline Length of Run, Minutes & 51 & 39 & 39 & 18 & 63 & 125 & 98 & 140 & 20 \\
\hline Air Flow LB/HR & 8640 & 7020 & 6840 & 7056 & 9720 & 6840 & 7200 & 6840 & 6912 \\
\hline Dry Manure or Wood LB/HR & 468 & 398 & 371 & 378 & 433 & 315 & 380 & 325 & 272 \\
\hline Propane Feed LB/HR & 7 & 6 & 6 & 6 & 7 & 5 & 6 & 5 & 6 \\
\hline
\end{tabular}

The two main differences in wood and manure were the quantity of ash generated and accumulation of slag in the combustor. Removal of ash particles presented no operational problems. Melting of ash on the refractory linings was a severe operational problem. Reference is made to figure 6 which shows the refractory lining in the combustor. During combustion of the manure the refractory liner became coated with molten ash which coalesced forming solid lumps of baseball size that became detached and fell into the combustor outlet. The result was that after approximately two hours of running the flow at the combustor outlet was choked, causing the compressor to surge. Surging of a compressor causes damaging instabilities in the system that cannot be tolerated. It can be seen from the data of Table 3 that the runs were relatively short, the longest being 140 minutes. To complete further runs it was necessary to remove and clean the ducting at the bottom of the combustor. After twelve hours of operation, the upper 
part of the chamber became so congested with slag that the combustor had to be removed and cleaned. The slagging occurred only on the refractory surfaces. There was no slagging on the metal ducting or the walls of the cyclone filters. Figure 10 shows the insulated combustor hanging ready for reinstallation into the burner housing.

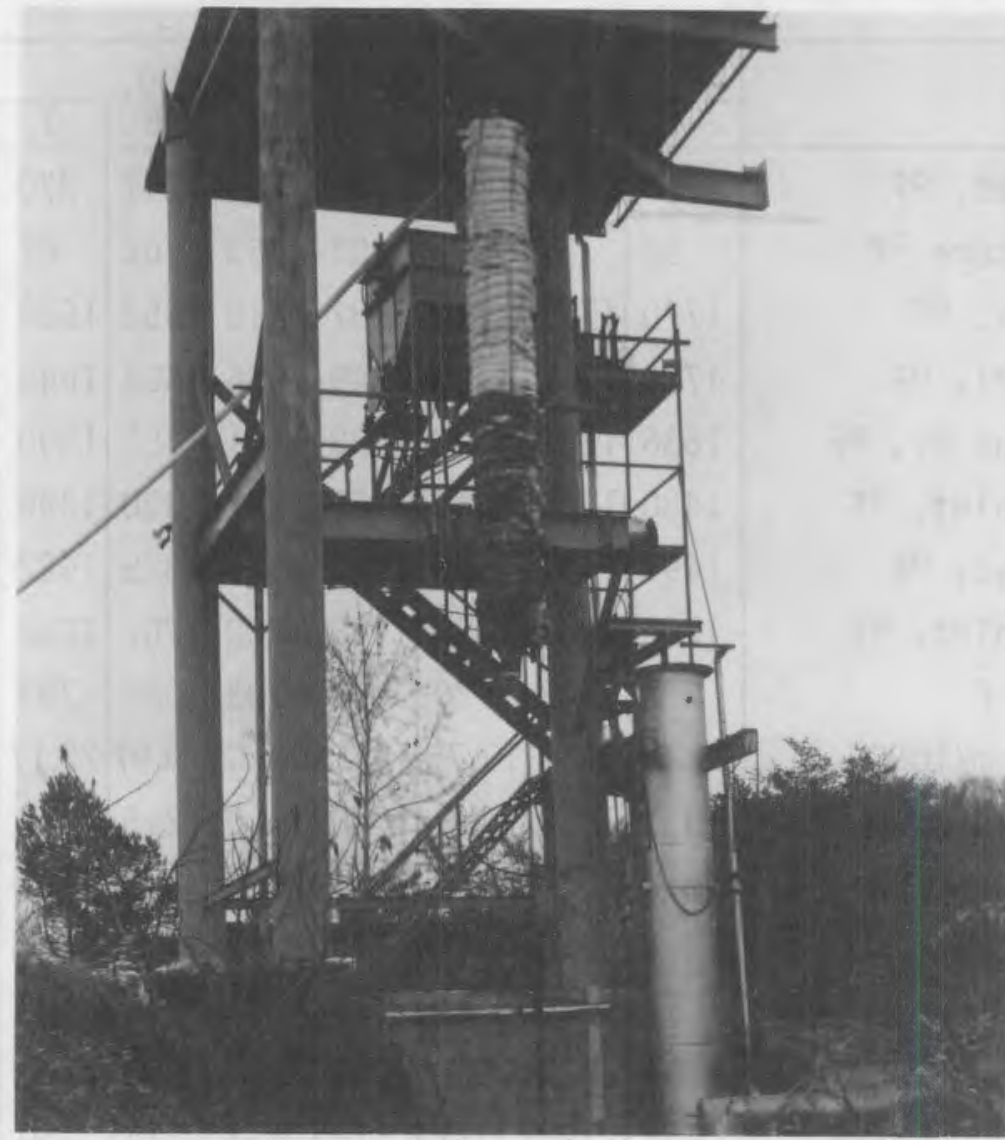

FIGURE 10. Insulated Combustor Ready for Installation in Combustor Housing at Lower Right.

The inside diameter of the refractory as shown in figure 6 is 11 inches. The metal shell was modified so that a refractory liner 14 inches in diameter would fit inside. With this modification it was possible to run six hours with reduced manure feed before surging occurred, allowing emission measurements to be made.

\section{EMISSION MEASUREMENTS}

The inability to make extended runs due to slagging of the combustor presented a problem in making emission measurements. To provide the running time required to make the measurements it was decided to run with a higher percentage of propane. It was reasoned that if the manure feed were reduced to approximately one third of that fed in the preceding runs the time before choking of the combustor outlet could be increased to six hours. 
The average feed for preceding runs was approximately $350 \mathrm{lbs} / \mathrm{hr}$ (dry basis). Therefore, the runs for emission measurements were made with $1001 \mathrm{bs} / \mathrm{hr}$ (dry basis). To keep the propane feed under 50 percent of the total (Btu basis), it was necessary to run at engine speeds of $19000 \mathrm{rpm}$ or less. Under those conditions of operation particulate mass, particle size distribution, and gaseous emissions were measured by Paul Webb of Battelle Columbus. The Battelle Report is contained in Appendix 5. The results suggested that the particulate material contained primarily potassium chloride and sodium sulphate. The gaseous emissions contained relatively high levels of carbon monoxide, sulfur dioxide, and ammonia. The particulate concentration ranged from 392 to 553 parts per million with 8 percent exceeding 5 microns. That concentration exceeded what was predicted, and it is probable that three cyclones will be required in a commercial system. For turbine inlet temperatures at $1450^{\circ} \mathrm{F}$ or less, corrosion may not be a major problem for the inconel turbine blades.

There was no obvious significant corrosion of the metal ducting or of a probe inserted into the duct upstream of the turbine following 20 hours of testing.

\section{DISCUSSION OF RESULTS}

The objective of the manure evaluation program was to determine if feedlot manure can be used to fuel a gas turbine in the same manner as wood. It was reasoned that one way to achieve conclusive results was to operate the previously wood fired system on manure for at least 300 hours. With the advent of the slagging problem most of the experimental effort was expended on modifications to eliminate $i t$, and at the same time to make as many runs as possible within the confines created by the slag build up. Only 20 hours of operation was achieved. However, the running that was accomplished shows that if the slagging problem can be resolved the remaining operational aspects of manure use as a gas turbine fuel are manageable. There were no slagging problems except on the refractory. The ash was collected in the cyclones and periodically removed from the lockhoppers below the cyclones without difficulty. Difficulties were encountered with the flexible auger in the feed train, but its replacement with a pneumatic conveyor solved the problem. Aside from the problems that may be encountered in corrosion of turbine blades or in coating them, as is being encountered with oak wood, the major problem lies with the combustor. Slagging results from ash particles impacting combustor wall surfaces which are at a higher temperature than the melting point of the ash. This problem, which occurs with refractory lined combustors was also encountered by the Australians (8) in their gas turbine research with brown coal. Initially it was feared that with sawdust and pulverized wood similar problems would be encountered. However, there was no problem with wood as the large sizes of the particles prevented the rapid combustion that takes place with powdered coal and manure. It is difficult to avoid pulverizing the manure to much finer sizes than wood. Fine wood powder can produce the same problem. Trouble was encountered with sander dust in the refractory lined burner in earlier tests. The finer, lighter weight particles were centrifuged out against the hot walls. Com- 
bustion was so intense that the surface of the refractory, which had a melting temperature of $3400^{\circ} \mathrm{F}$, melted and spalled off.

The Australians (8) successfully developed an all metal combustor with less centrifuging and a 97 percent combustion efficiency for use with brown coal. One source of difficulty with development of an all metal combustor came with keeping the flame stable while encountering irregularities with the coal feeding system.

The blue haze observed in the exhaust gases may result from failure to completely burn carbon particles shed from the ash and dirt in the cyclones. Combustion will be more nearly complete at the higher pressures and high combustion air inlet temperatures. Air is delivered by the compressor of the Allison T-56 engine at 650 to $700^{\circ} \mathrm{F}$ and at pressures from 110 to $150 \mathrm{psia}$. However, the twenty five percent ash and dirt in manure, compared to one to two percent in wood, may preclude the continuous generation of a visibly clear exhaust.

The role of chloride salts in slagging is yet to be defined. As noted earlier the melting points of the chlorides range from 1421 to $1473^{\circ} \mathrm{F}$. With the restriction of turbine inlet temperature to $1450^{\circ} \mathrm{F}$ or less, it may be difficult to make a determination.

\section{RECOMMENDED FURTHER RESEARCH AND DEVELOPMENT}

There are at least three major areas of needed investigation. They are development of a suitable combustor, long term operation, and fuel preparation.

\section{DEVELOPMENT OF A SUITABLE COMBUSTOR}

The temperature of the walls of the combustor must not equal or exceed the melting temperature of the manure ash. Due to the fast burning rate of the pulverized manure the refractory materials in the combustion zone rapidly reach or exceed the ash melting point. A review has been made of the work by the Australians in the development of all metal combustors for pulverized brown coal. Use of air cooled metal walls solved their slagging problems. Because of their success, it is recommended that a research and development effort, organized along the same lines, be pursued with regard to manure. Alternate methods of thermochemical conversion of manure for use with gas turbines include gasification and fluidized beds. A major problem with gasification was encountered with waste water disposal $(9), 10)$. The use of fluidized bed combustion in the same manner as for coal (7) may prove to be a viable alternative. The temperature of the bed can be kept well below the melting point of the ash. The higher pressure drop across a fluidized bed than for a direct combustion chamber may create a surge problem with the use of off-the-shelf gas turbines. 


\section{LONG TERM OPERATION}

Upon development of a suitable combustor long term operation of a gas turbine should follow to evaluate erosion, corrosion, and coating of the turbine blades. The coatings now in use on the blades of the Allison $501 \mathrm{~K}$ turbine may be effective in preventing erosion and corrosion. The FeCrAlY and CoCrAlY alloy coating (7) can also be evaluated with manure if the need arises.

\section{FUEL PREPARATION}

A three pronged approach is needed on fuel preparation. They are separation of sand and rock by methods discussed in Appendix 3, drying of manure with gas turbine exhaust gases, and feeding of a manure water slurry into the combustion chamber.

Separation of Sand and Rock

Residue from combustion of manure in excess of approximately 18 percent consists of rocks and dirt scraped up with the manure in the feed lots. The rocks are broken up in the hammermill and have not presented a problem except for small rocks that move into the live bottom and jam the metering auger. In the investigations reported herein, accumulations of rocks were periodically removed from beneath the hammermill screen by hand. They collected there because they were too heavy to be moved by the blower that pulled in the lighter weight manure particles and conveyed them to the feed bin. Assuming that the manure will continue to be fed dry, a more satisfactory method of separating.the rocks will need to be devised.

\section{Drying of Manure}

Because of the sticky nature of wet manure, it is not believed that the fluidized bed dryer developed for pulverized wood and sawdust will be suitable for manure. A moving, self cleaning metal belt that conveys the manure beneath downward spouting tubes of hot gas appears to be one possible method that should be evaluated. In this program, some success has been achieved in drying manure spread on concrete and subjected to blasts of hot air from a kerosene fired heater. Commercially available dryers that have been evaluated do not appear to have adequate capacity. A survey of commercial dryers is continuing.

\section{Manure-Water Slurries}

Fred Sparber, of New Mexico, a long time researcher on methods of converting feedlot manure to useful energy, has suggested that burning of manure in the wet condition may be possible. At his request, manure-water slurries were evaluated, and it was determined that feedlot manure samples with 49 percent moisture (wet basis) exhibit a toothpaste consistency which may be capable of being pumped and sprayed into the combustion chamber. As pumping of slurries is an old art the application to manure-water slurries should not be difficult. A manure-water slurry sprayed into a flame zone supported by $670^{\circ} \mathrm{F}$ combustion air at 130 psi may burn well if it can be 
atomized in the process. Some lumping of the manure particles may result from the pumping pressure. Any lumps that are formed will have to be immediately disintegrated. Dry manure or fossil fuels would have to be used during system warm up at which time both system pressure and air temperature are low. Use of slurries is a direction of effort that could simplify the feeding problem and eliminate the drying requirement. If it should prove necessary to wash some of the chlorides out of the manure the approach could prove quite advantageous. This is a direction of research effort that is quite different from the present one, and it should be given further study.

\section{SUMMARY OF RESULTS}

The results of the investigation may be summarized as follows:

1. Manure can be pulverized and fed into a gas turbine combustion system in the same manner as pulverized wood or sawdust.

2. The manure burns in much the same manner as a liquid or gaseous fuel.

3. Slagging occurs on the hot refractory walls of the combustor causing severe problems. Development of a suitable combustor will be required before a commercial size system can be designed.

4. The ash and dirt do not appear to have a significant effect on combustion stability and are effectively removed by the cyclone filters.

5. The manure exhaust gases vary visually from clear to a blue haze.

6. Emissions tests show the particulate emissions with only two cyclones to exceed EPA requirements. The $\mathrm{NO}_{x}$ and $\mathrm{SO}_{2}$ levels are relatively high but fall within the EPA limits for fossil fuels. High levels of $\mathrm{CO}$ reflect the poor performance of the combustor.

\section{ACKNOWLEDGEMENTS}

In pursuing the foregoing research and development the assistance of Messrs. Mark Gerber and Gary Schiefelbein of the Battelle Pacific Northwest Laboratory and Simon Friedrich of the Department of Energy are greatly appreciated. 


\section{APPENDIX 1}

\section{REFERENCES}

1. Crop, Forestry and Manure Residue Inventory - Continental United States Volume I, Stanford Research Institute, Menlo Park California 94025

2. Hamrick, Joseph T. and Hamrick, Thomas M., Application of Cyclone Filters to Wood Burning Gas Turbines, A Symposium on Particulate Laden Flows in Turbomachinery ASME Conference at Saint Louis, Missouri, June 1982, Library of Congress 82-71170.

3. Hamrick, Nancy A., Development of Wood as an Alternative Fuel for Large Power Generating Systems Part 3: Computer Simulation of the Dynamic Response of an Industrial Gas Turbine with Large Volume Combustion and Filtering System, Aerospace Research Corporation Final Report DOE/ET/ 20058-T2(Pt3)(DE82001992), September 1981.

4. Blackshear, Perry L., Jr., Development of Wood as an Alternative Fuel for Large Power Generating Systems Part 5: Soot Formation in Suspension Burners. Aerospace Research Corporation Final Report DOE/ET/ 20058-T2(Pt5)(DE82002032) July 1981.

5. Giese, E.P. and Leesley, M.E., Development of Wood as an Alternative Fue1 for Large Power Generating Systems Part 4: A Mathematical Model of Burning Wood Chips, Aerospace Research Corporation Final Report DOE/ET/20058-T2(Pt4)(DE82001990) July 1981.

6. Hamrick, Joseph T. and Hamrick, Thomas M., Development of Wood as an Alternative Fuel for Large Power Generating Systems Part 1: Research on Wood Burning Gas Turbines, Aerospace Research Corporation Final Report DOE/ET/20058-72 (Pt1)(DE82002034) September 1981.

7. Roberts, A.G., Barker, S.N., Phillips, R.N. et al, Fluidised Bed Combustion, NCB Coal Utilisation Research Laboratory Final Report, Department of Energy Report FE-3121-15(a), 1980.

8. F.L. McCay, Chairman, The Coal-Burning Gas Turbine Project, ISBN 0642001499, Australian Government Publishing Service 1973.

9. Beck, Steven R., Wang, Maw-Jong et al, Biomass Gasification in the SGFM Process, Texas Tech University. Presented at Thermochemical Conversion Contractor's Meeting, U.S. DOE Biomass Energy Systems, Roanoke, Virginia April 24-25, 1979.

10. Wakamiya, Will and Maxham, John V., Treatability of Biomass Gasification Wastewater, Battelle-Pacific Northwest Laboratory. Presented at Biomass Thermochemical Conversion Contractor's Meeting, Berkeley, Cal ifornia, February 12-13, 1980. 
APPENDIX 2

CHEMICAL ANALYSES OF FEEDLOT

MANURE FROM CLOVIS, NEW MEXICO 


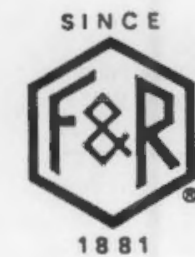

FROEHLING \& ROBERTSON, INC.

FULL SERVICE LABORATORIES - ENGINEERS \& CHEMISTS

"OVER ONE HUNDAED YEARS OF SERVICE"

1881

September 24, 1984

No:

Analysis of Manure

Made For: Aerospacé Research Corp.

5454 Jae Valley Road, S.E.

Roanoke, V1rginta 24014

$\begin{array}{ll}\text { Marked: } & \text { (1) Old Manure } \\ & \text { (2) New Manure }\end{array}$

P.O. No. FA 6486

0

0

(1)

(2)

Btu per Ib.

Carbon, $\%$

Hydrogen, $\bar{~}$.

Nitrogen, $z$

Oxygen, $\%$

Ash, $z$

Sulfur, $z$

Chlorine, $z$

Molsture, 7

4263

24.67

3.39

6240

2.18

39.43

5.05

16.35

2.34

48.96

21.92

0.55

24.76

0.29

0.67
2.39

3.61

3.44

Respectully,

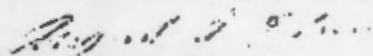

Augúst A. Thieme

Chief Chemist of Director

Chemical s Blological Services

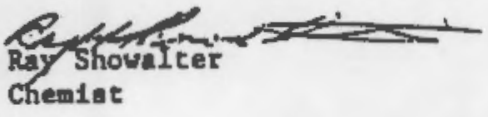

HEADOUAATE AS: 3015 OUMBARTON MOAO • OOX 27524 RICHMOND. VA 23261 . TELEPHONE AAEA COOE (OOA) 2B4-2701

OMAMCHES: ASHEVILLE, NC • BALTIMOAE, MO • CHARLOTTE, NC • CRO ET T. VA • GAEENVILLE, SC • NOAFOLX, VA • RALEIOH, NC • ROANOKE, VA • STEMLINO, VA.

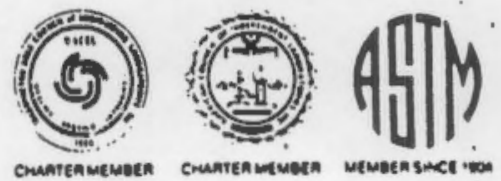




\section{-ANALYTICAL RESULTS REPOAT-}

Mr. Mike Kneisley

AEROSPACE RESEARCH CORPORATION

5454 Jae Val,ley Road, S. E.

Roanoke, Virginia 24014

RE: Manure Analysis

CAS Commission No. 6521

REPORT DATE/NUMBER: 20 MaY 1986/3

SAMPLE COLLECTED BY: Aerospace Research Corp: Personnel

SAMPLE RECEIVED IN LAB: 07 ApriI 1986: 0900

ANALYSIS FOR: Chloride, Total Volatile Solids (TUS), Nitrate (NO-3), Total Kjeldahl Nitrogen (TKN), Metals Superscan, Total Nitrogen (Total N), Carbon (C), Percent Nitrogen ( $\mathrm{N}$ ), Calcium (Ca), Iron ( $F e$ ), Silicon (Si), Sulfur (S), Sodium (Na), Potassium (K), Ash, Percent (\%) Moisture

METHOD OF ANALYSIS: Inductively, Coupled Plasma Emission (ICP);

- Federal Register, Vol. 40, Part 136, 26 Oetober 1994;

EPA $5 \mathrm{H}-946$

The results of our testing are reflected on the following page.

Upon recelpt of the for agoing and enclosed information, should you have any questions concerning same, please feel free to contact the undersigned at the letterhead address.

Prepared by:

CENTEC ANALYTICAL SERVICES

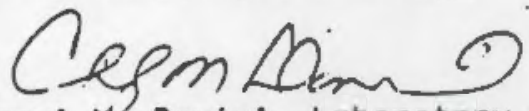

Cheryl M. Daniel, Laboratory Manager

CMD Id 1 t

Enclosure as Stated

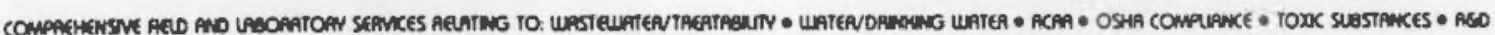


Page Two/Report No. 3

20 May 1986

CAS Commission No. 6521

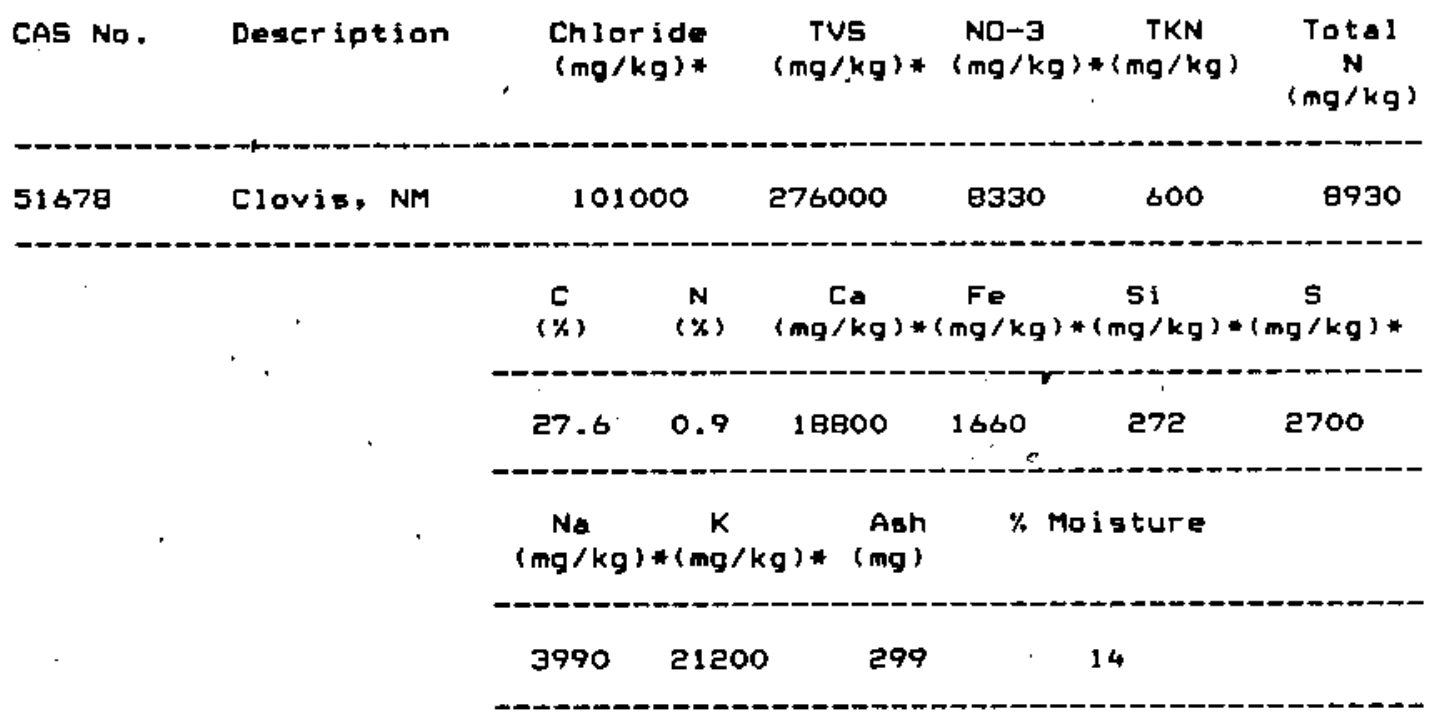

* Dry Weight Basis

NOTE, Data shoets for the 73-Element ICP Superscan are enclosed. The following oleiments were found at a concentration greater than twice that of the preparation blank:

Magnesium
Carbon
Copper
Erbium
Zine
Cosium
Calcium
Iron
Aluminum
Strontium
Boran
Silicon
Manganese
Sodium
Potassium




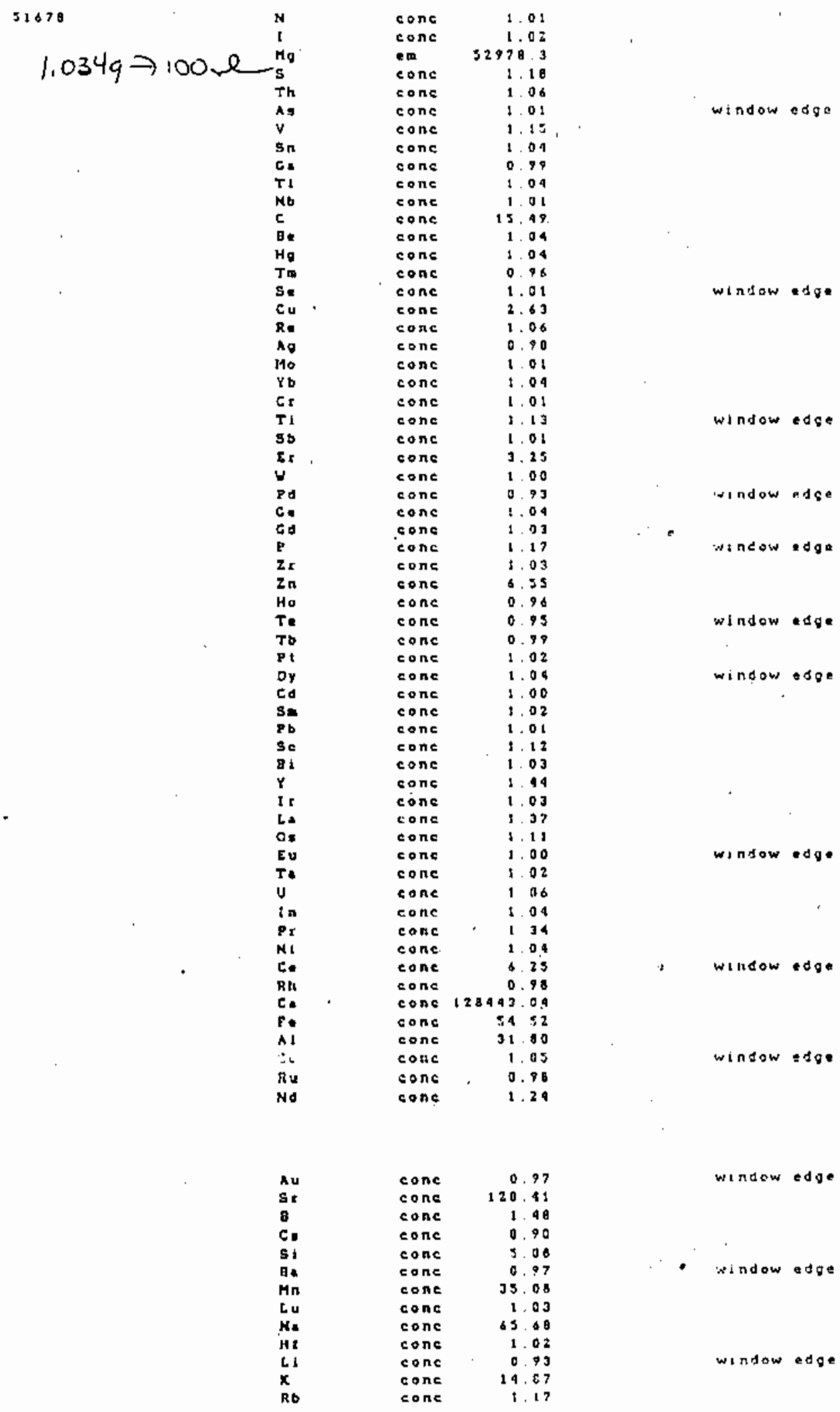


APPENDIX 3

SEPARATION OF ROCK AND SAND FROM DRY FEEDLOT MANURE

BY FREDERICK J. SPARBER

Rock and Sand down to 200-300 microns can be separated wth available classifying technology. The separation can be accomplished with the combined use of mechanical 1mpact-acceleration equipment and/or air.

A comprehensive study encompassing evaluation of commercially avallable, off-the-shelf, classifying equipment and equipment that could be readily fabricated was undertaken. The bulk of commercially available equipment is made for classification according to particle size as opposed to size-density. Many manufacturers of classifying equipment were contacted and the density separation question was addressed. The consensus was that if a uniform size or group of sizes could be provided, then the available equipment could be modified to effect the separation.

The removal of rocks ie; matertal of size greater than the largest undigested biomass material such as grain kernels (wheat, barley, corn or corn kernel fragments etc.) can be removed by a screen.

The difficulty comes in arriving at a process that can discriminate between a given size particle of biomass and an equivalent size grain or sand. From this the only physical property that can be exploited for separation is the specific gravity or density. In a wet process where water can be used in a sink-float application such as in a "pond" where the higher density material settles out this would be a simple and easy problem to solve. However, the use of air, kinetic energy and gravity poses some complex and difficult probIens.

Imparting kinetic energy to the materfal with air, fans or rotor-paddles is no problem and the energy requirement for 30 or so tons per hour at useable velocities of 20-30 feet per second is in the fractional horsepower range. Once the material has been given the initial velocity then separation by gravity in air becomes a problem of ballistics and aerodynamics and in this case every particle of a given size density and shape or groups of particles of random size density and shape must be treated mathematically to determine effective separation. For instance, if a rotor 6 inches in diameter, as in 
Figure 1, turning at $36 \mathrm{Ft} / \mathrm{Sec}$. impacts a material that is a mixture of sand

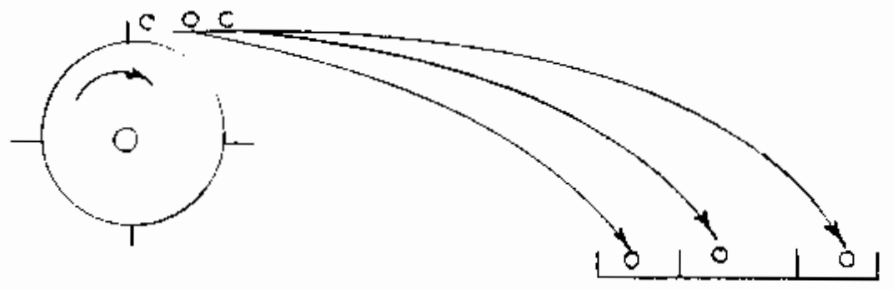

Figure 1 - Rotor Paddle

and biomass with a size range of .125 to .250 inches, the material will instantaneously be accelerated to $36 \mathrm{Ft} / \mathrm{Sec}$.

Then if one invokes the drag force equation, $F_{d}=.5 C_{d} P V{ }^{2} A$ where $C_{d}=$ drag coefflcient, $P=$ density of air, $A=$ area of particle. From this since $F=M a M=$ mass, $a=$ acceleration then $a=\frac{F_{d}}{M}=\frac{.5 C_{d} V 2 A}{M}$, actually in this case acceleration is negative or what we call deceleration. Thus the application of this equation as $-a=\frac{\cdot 5 \mathrm{C}_{\mathrm{d}} \mathrm{V}^{2} \mathrm{~A}}{\text { spectfic gravity }}$ and application of the equation for the settling velocity in still air $\mathrm{V}_{S}=24.9$ (DS) $\frac{1}{2}$ where $\mathrm{D}=$ particle diameter (microns) and $S=$ density of the particle. From this the trajectory of the particles can be estimated and only estimated because of the uncertainty of ${ }^{\prime} C_{d}$ and the shape factor which has recently been studied in particle ballistics as a parameter that can swamp the accepted values of $C_{d}$.

Conclusion: If the material is screened into groups of sizes such as $1 / 8$ to $1 / 4,1 / 16$ to $1 / 8,1 / 32$ to $1 / 16$ etc. separation can be effected with fans, impingers or updraft fluid colume. 


\begin{abstract}
APPENDIX 4
THEORETICAL PERFORMANCE OF THE ALLISON T-56-15 GAS TURBINE WITH AND WITHOUT WATER/STEAM INJECTION
\end{abstract}

NANCY $H$. OWEN 
GENERMLSSRC IRUN GENRUNI, OCTORER, 1906 VEREION
14DQ. TUREINEU INLET

STEN TNJECTION IS NOT USED IN TH1S STSTEM.

OMnöronuECr AMBIENT PRESSURE $29.92 \mathrm{IN}$, $\mathrm{HE}$.

D PUEL PATTI CULARS:

\begin{tabular}{c} 
MTU \\
MANURE \\
\hline
\end{tabular}

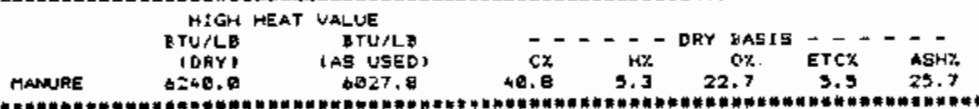

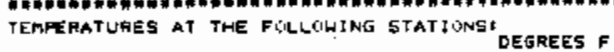

AMIENT

COMPRESSIRA INLET
COMPRESSCA OTTLET

TURPINE INLET

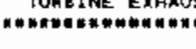

PRESSURE AATIO

MASS FLOWW (LQS SEC)

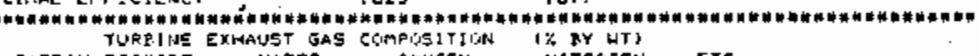

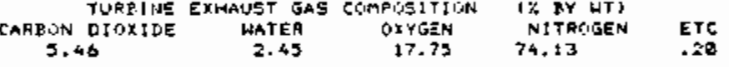

ASH DUMPED THRU CYCLONE IS .332 L2/3EC STEAM GENEFATIJH+1 2.7 LB/SEC a LES F FAGM (EXCESS) EXHAUST GAS MEAT a 80.0 \% EFF

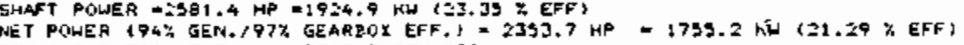

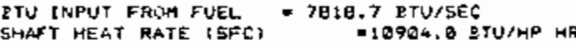

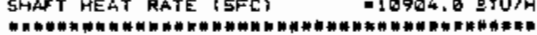

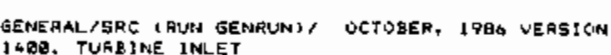

MANURE

STEAM INJEECTION IS NUT USED IN TH1S SYSTEM.

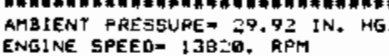

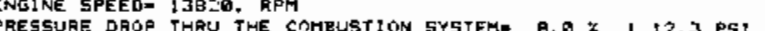

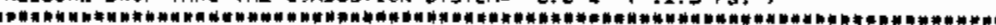

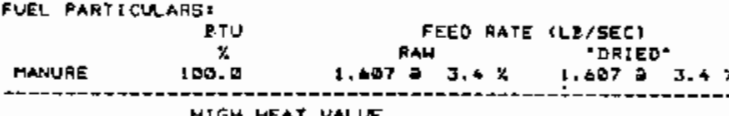

HIGH HEAT VALUE
PTULLB HTUAB

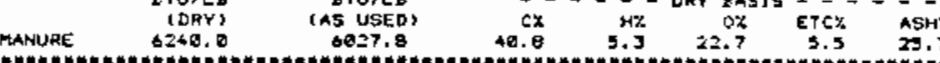

TEIETT DEGEES

AMIENT

COMPRESSUA INEET

TOMPRESSOR GUTLET
TURBINE INLET
TUREINEXHAUST

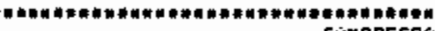

PRESSUAE RAT IO

MASS FLELW TLE/SEC

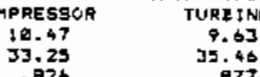

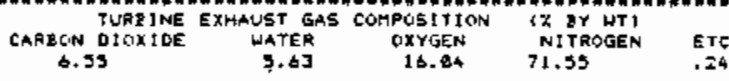

ASH DUMPED THRU CYCLGINE IS 399 LB/SEC

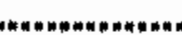

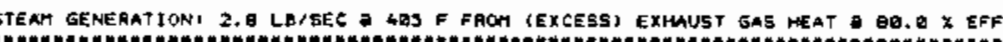
GHATT POHER

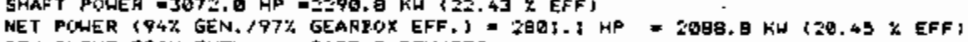
BTU INPUT FPOM FUEL $=9097.0$ BTW/SEC

SHAFT HEAT RATE (SFC) 11391.9 BTU/HP HR 


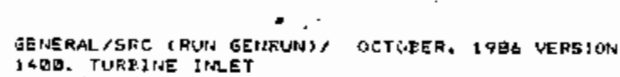
MADUTEE TURPRTE INLET

SIEAM INJECTISTN IS NOT USED IN THIS SYSTEM.

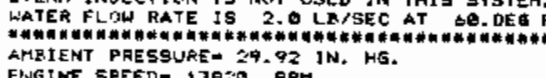

FFESSURE DRUP TKRU THE COMBUSTJON EYSTEM- $a, 1,12,7$ PSI

FUEL PARTBCULARS:

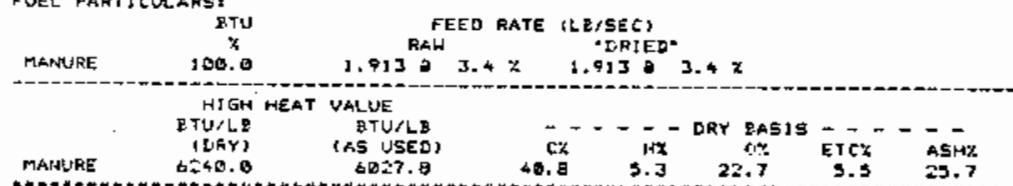

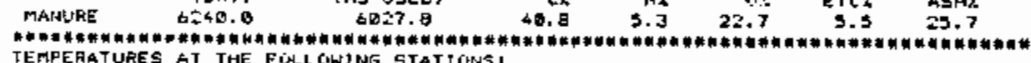

AMRIENT DEGREES $F$

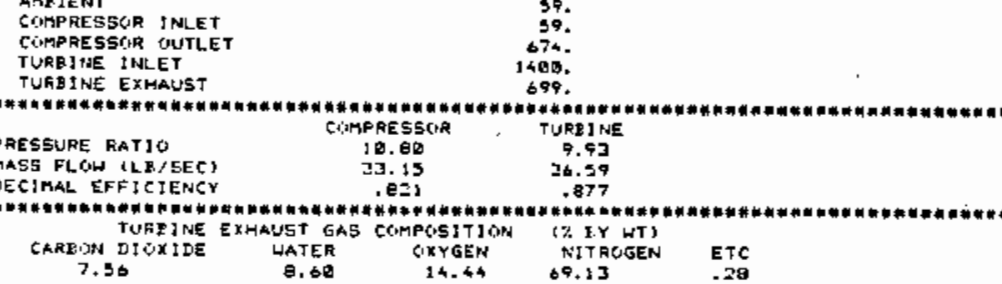

ASH DUMPẼd THAU CYCLGHE IS .475 LB/SEC

AGH DUMPEO THAU CYCLGNE IS 475 LB/SEC

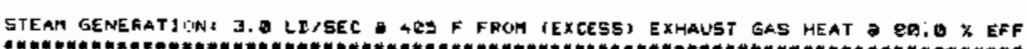

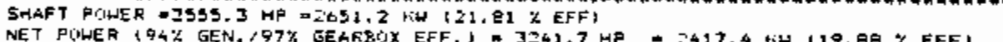

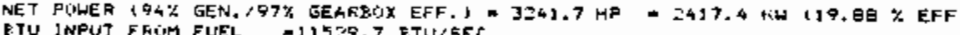

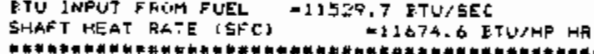

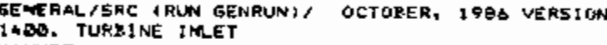

STEAM INJECTISON IS HOT USED IN THIS SYSTEM.

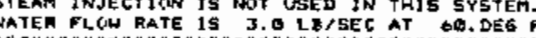
AMRIENT PRASSUE- $\because 9.921 \mathrm{~N}$. HO.

PRESSURE DROP THRU THE COMBUSTICN SYSTEM- $0.0 \%$ ( 33.1 P5I

FTU RATE (LP/SEC)

MANURE $100^{\mathrm{X} .3} \quad 2.217^{\text {RAW }} 3.42 \quad 2.21723 .4 \mathrm{Z}$

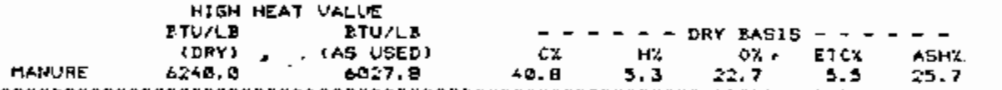

TEMPEATTURS AT THE FOLLLOWITHG STATJONS I

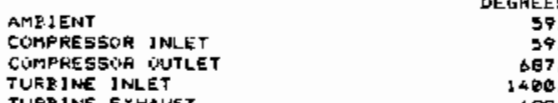

PRESGUFE FATI

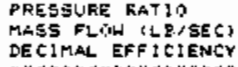

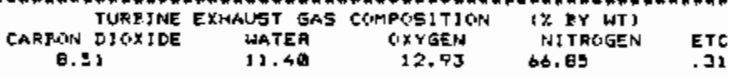

A5H DUMPED THPU CYCLONE IS .SSE LB/SEC

STEAM GENERATICN 3.2 LB/SEE a 4 ES F FROM (EXCESS) EXHAUST GAS MEAT O BQ.D Z EFF

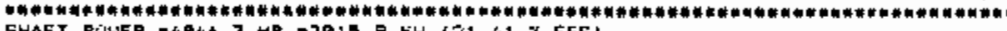

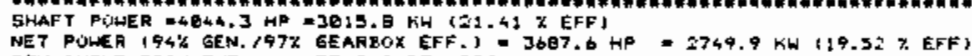
NET PUHEA 194\% GEN. $197 \mathrm{X}$ GEARBOX EFF. I - 3607.6

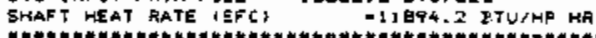


STEAPY INJECTICUN IS NOT USED IN THIS SYSTEM.

unumanom AMNEENT PKESSUFE 29.92 IN. HG.

PRESSLIFE DROO THRY THE COMPUST TON EYSTEMO OPO

FUEL PAFTICULARS $x$
MANURE
108.9 BTUJLR HEAT VAL GE

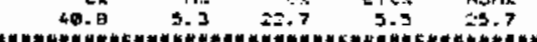

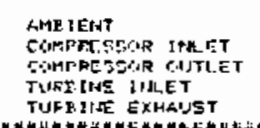

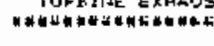
FFESSURE RAT 10
MAS FLCW TLPECI
DECIMAL EFFICIERCY

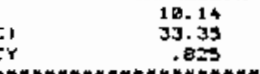
DEGREE $F$

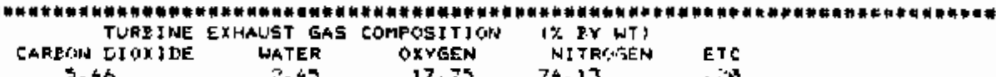

ASN DUMPED THPU CYCLGIME 15 , $32=$ LF THHAT POSWEF

PTU INPUT FFIM FUEL $=7818.7$ PTU/SEC

CIK KMaL E.FFICTENCY $-33.33 x$
14RG. TURPINE INLET

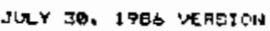

STEAM FLOW RATE IS 1.0 LB/SEC AT 403 . DEG F

AMXIENT PRESSURE

PFESSURE DACIP THRU THE CCMEUSTION SYSTEM- $9.0 \%$

FUFL PRPTICULARS: ETU FEED RATE ILE/SEES

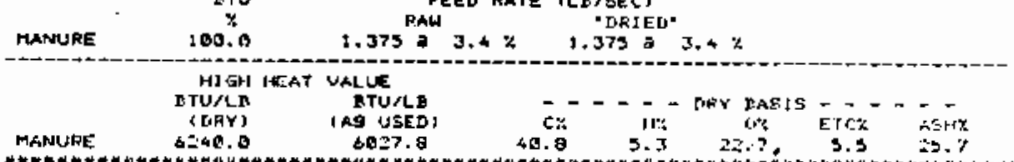

TEMPEFATI!IES AT THE FGLLOWING STATIONS! DEGREES

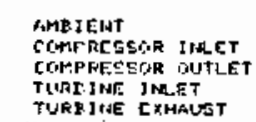

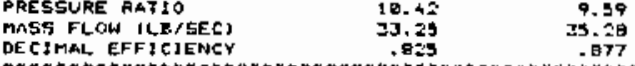

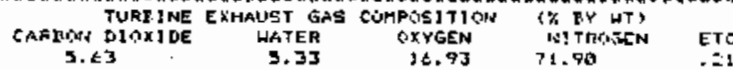

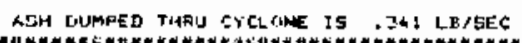

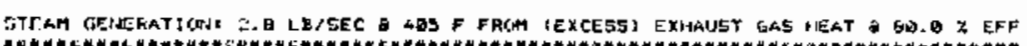
SHAFT PQWER

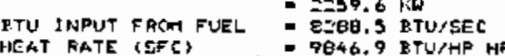

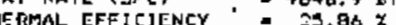

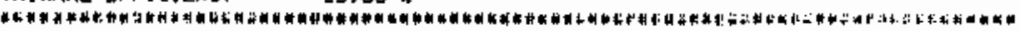


14RO. TUREINE IMLET

JULY. 30, 1980 VEPSTSt

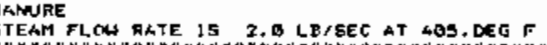

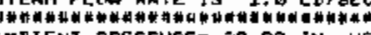

AMPIENT PRESEIYTE- 29.92 IN. MG.

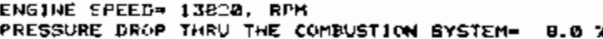

年

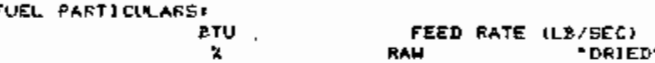

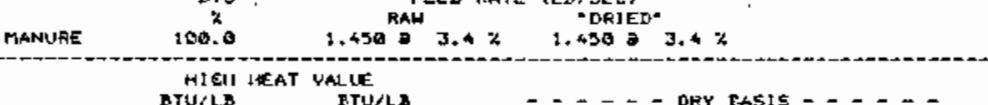

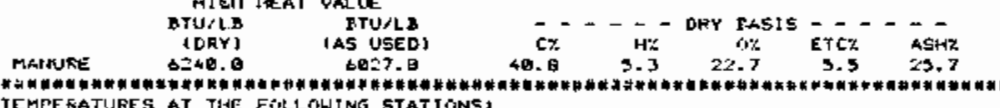

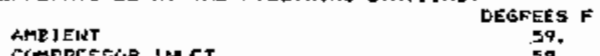

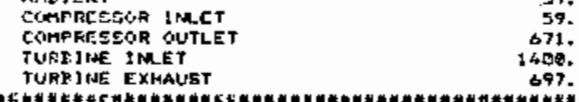

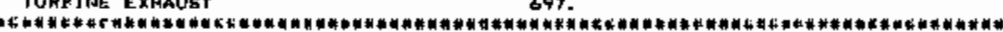

PFESSUPE RATIO

MASS FL TIW TLI ISECS

30.73
33.0

TURE. NE
9.87

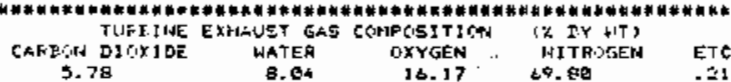

ASTH RUMFED THRU CYCL LONE IS -3SO LQ/SEC

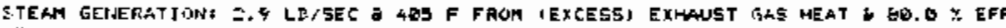
SHAFT POJER SHAFT PODER

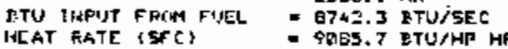

RRAL TFFICIEST
1408. TURBINE IMLET

JUR 38, 19B. VERSIGN

STEAH FLOL AATE IS 3.D LB/SEC AT 403.055 F

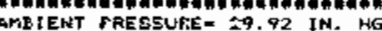

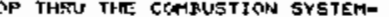

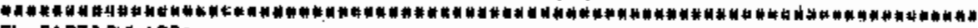

FEED RATE (LE/SEC)

MANURE

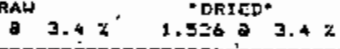

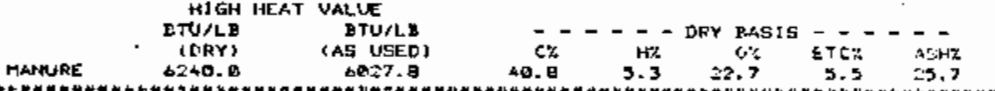

MANGRE TEMPERATUFES AT THE. FOLLOHING STATIONS:

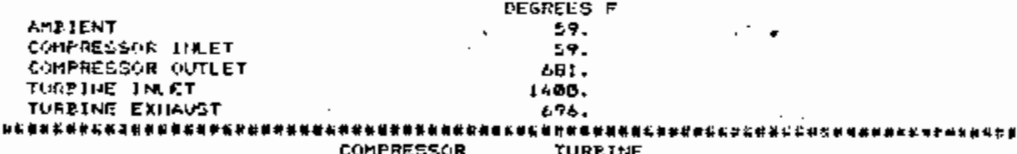

PRESSURE FATIO

COMPREESCIR KOAK WURE ITIE

PRESSURE FATIO
MAES FL L ILI IEECI
TEEIMAL EFFICIENCY

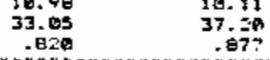

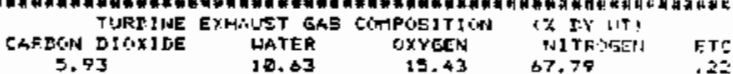

ACH DUMPED THRO CYELONE IS 379 LR/EEC

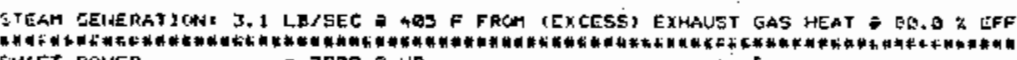
SHAFT POHER

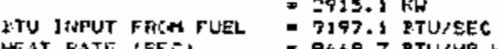

HEAT KATE. (5FE) $=8469.7$ PTU/HP HR

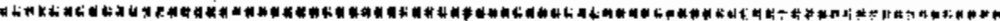




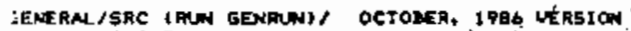
1450. TURBINE IMLET

GTEAT INJECTION IS NOT UBÉD IN TH:S EYSTEM.

ATER INIECTICW IS NOT USED IN TH1S SYSTET. MAIENT PRESSURE $=29.92$ IN. HG.

RESSURE DROP THRU THE CCABUSTION SYSTEM* $8.12 \times$ i 12.8 PSI,

PSI J JeL PARTICUR,Aas:

DTU TEED RATE (LE/SEC)

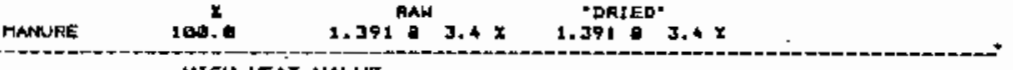

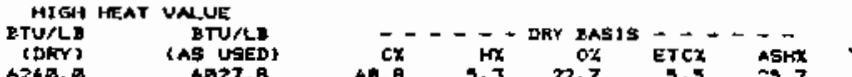
MANUAE GZ2KS: EMPERATURES AT TRE FQLLOWING STATIOASI DEGNEES F
GERERALSSAC IRUW GEMRUN" OCTOEER. 1966 MERSIOW

STEAM 1 NGECTION IS NOT WSED IN THIE EYSTEK.

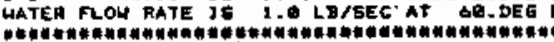

AME ! EMT PRESSURE- 29 M 2 : IN. Ho.

ENGINE SPEED- 13920. RPH

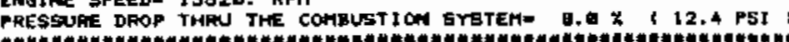

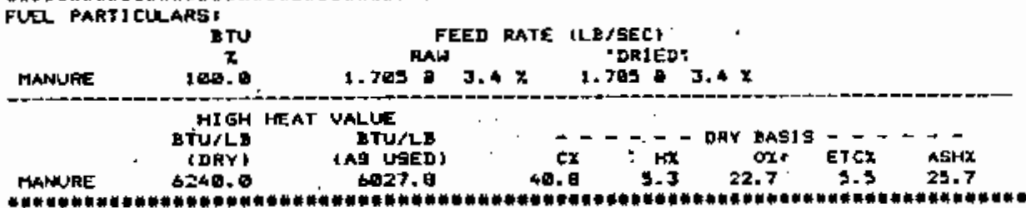

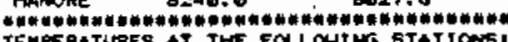

DEGRES $F$

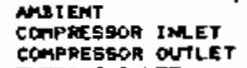

COMPRESSOR OUTLET
TURBNRE 1MLET
TURE INE EXHATET

年

PREESURE RATIO

MASS FLCA (LH/SEC)

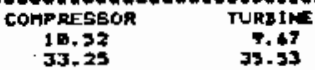

GFFICJENCY

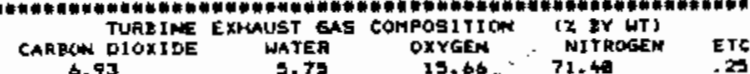

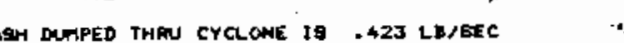

ASH DMTPED THFN CYCLONE I9 $\quad 423$ LB/GEC

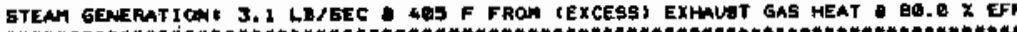

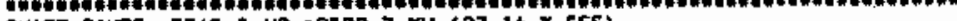
SHFT ROAEF 2TU INPUT FAOW FUTL -10275.3 ETU/SEC J

DHWT HEAT MATE (SFC) DE

ASH DUMPED THAN CYCLONE IS . 345 LB/gEC

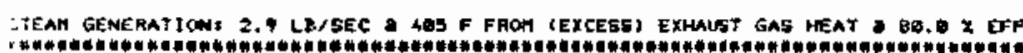

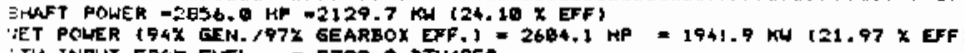

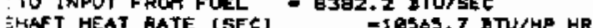

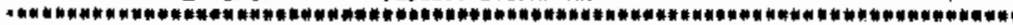


GEEERAL/SRC ARUN GENANNI), PCTOBER, 1986 VERSION

MANURE
STEAM INJECTION IS NOT USED IN TH1S EYSTEM.
WATER FLOW RATE IS

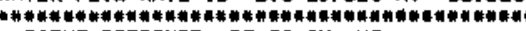

AMEIENT PRESSURE- 29.92 IN, HS.

PRESSURE DROP THRU T TE COMBUETION SYSTEM- $8.8 \%, 12.7$ PEI

FUEL PAATICULARS

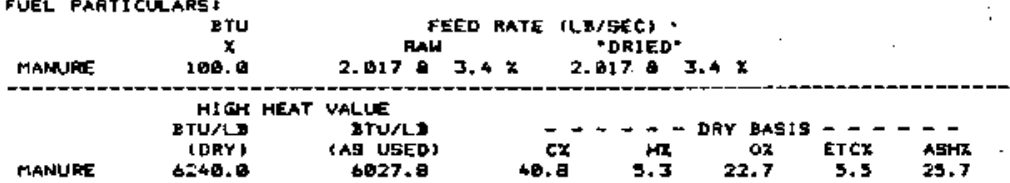

MANURE

BTU

(Ag USED)

$c x^{2}+3 x$

TETPERATURES AT THE FOLLOWING ETATIONS,

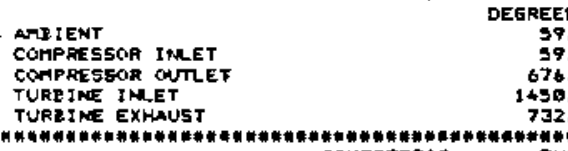

TUREINE EXHAUST

PAESSURE RATIO

MASS FLOW (LE/SEC)

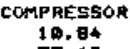

10.15
33.15
.621

CARBON TURBINE

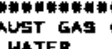

9.99
36.677 GREEE $F$

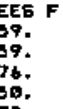

ASH DUMPED THRU CYCLONE 18 . SOI LR/SEC. STEAT GENERATION: 3.2 LB/SEC \& 405 F FROM (EXCEES) EXHAUST GAS WAT O OE. O XFF

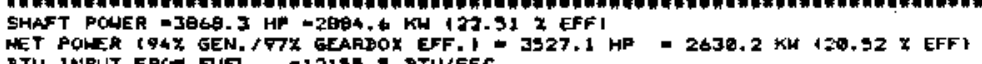

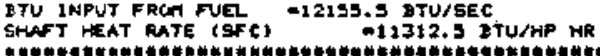

6EMERAL/ERC (RUN GERRUW") OCTOBER, 1986 VERSION THO. TRE JNE IMLE

STENH INJECTIOM IS NOT USED IN THIS SYSTEM. 年

FESSURE DROP THRU THE COHBUSTION SYSTEM- $8.0 \mathrm{z}+13.1$ PEI

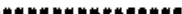

FTU FEED RATE TLB/SEC?

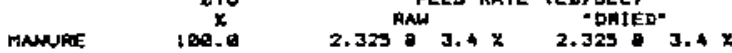

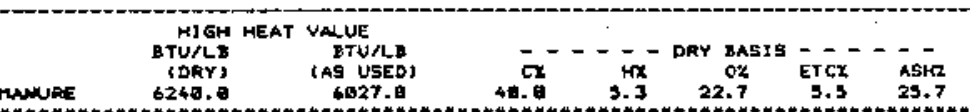

TEMPERATURES AT THE FOLLOWING STATIONS, DEGREES F

NMIIENT

COMPRESSOR IMET

TURPINE ITAET

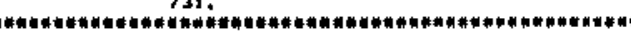

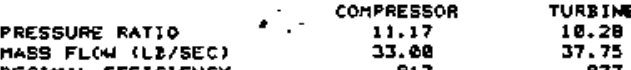

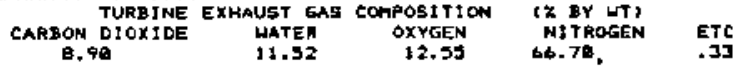

ASH DUMPED THPU CYCOARE 15,937 LE/SEC

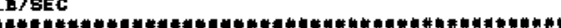

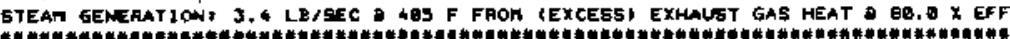

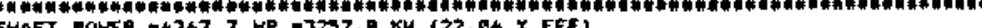

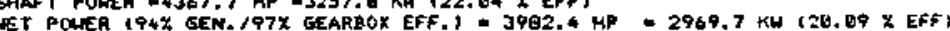
BTU INEUT FROM FUEL T14E16.8 ITU/SEC

SHAFT HEAT RATE ( $Q F()$, 
145Q. TUAB TME IMEET

JiRY 30, 1983 VERG ION

STEAM INJECTISN 19 NOT, GSED IN TNIS SYBTEM.

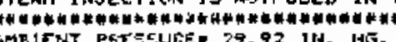

AME1ENT PFE ESURE. 29.92 11. HG.

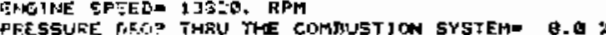

FUEL PART TCULARS:

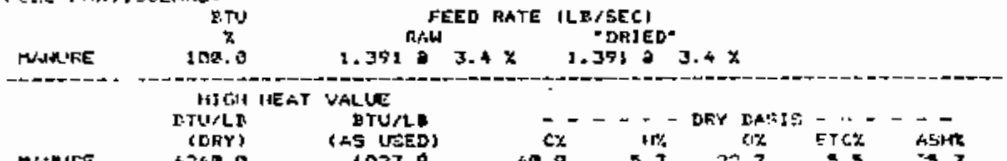

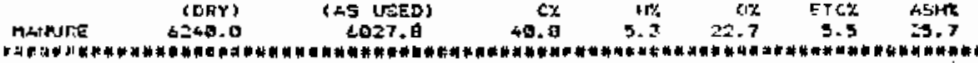

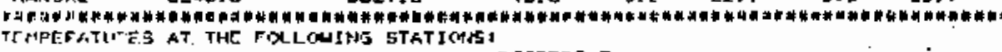
MENENT

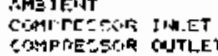

TURRYISE ITAET
TUREIME EXYHAST

1450

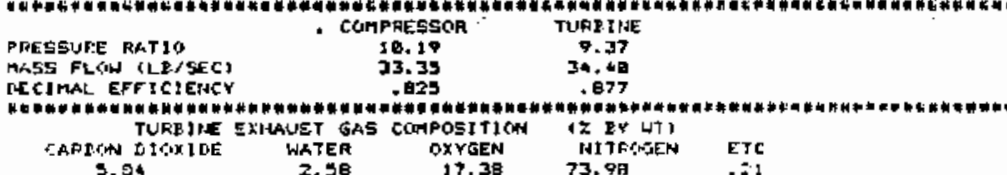

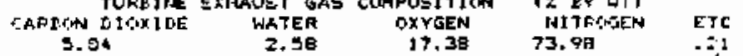

ASH DUMPED THRS CVCLONE IS . 34S LD/SEC

STLAM GEISRATILWE 2.9 LB/BEC 2 405 F FAOM IEXEESSI EXHAIST GHS HEAT 2 DO. 0 X EFF ShLST PGSTRR

TTU IINPIT FnOA FUR

IEAT RATE (IFE) * $295 \mathrm{a} . \mathrm{H}$

-10365.7 MTU/SEC

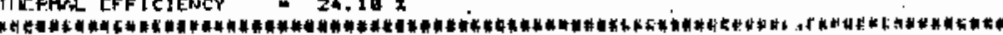

1450. TURTIRE 1MEET

JUY J9, 1996 YEFSION

STEN FLCW RATE IS 1, O LM/SEC AT 4DS. DEG F

PRESSUIFE BNOF THFU THE COMBUSTION SYSTEM- M.

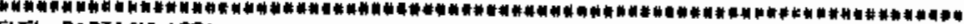
FuEl partjcurakst

BTU FEED TATE (LR/SEC)

MAINAFE $108.0 \quad 1.473^{\text {RAW }} 3.4 z \quad 1.473=3.4 \mathrm{X}$

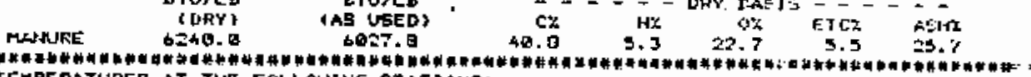

TEMPERATLIRES RT THE FOLLOUING STATIONG:

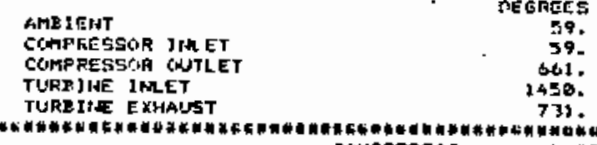

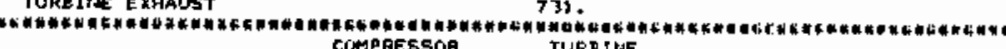

PRESSUPE RAT1O

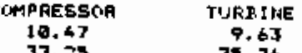

TSIS FLOW CLPJGEC,

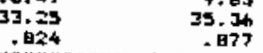

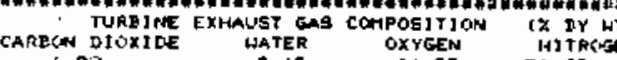

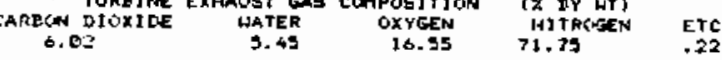

FSI DOMPED THAR CYCLONG 19 . 336 LE/SEC

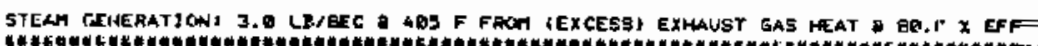

= $3471.6 \mathrm{KL}$

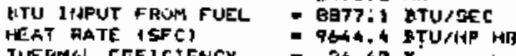

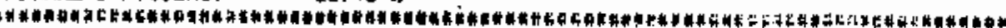




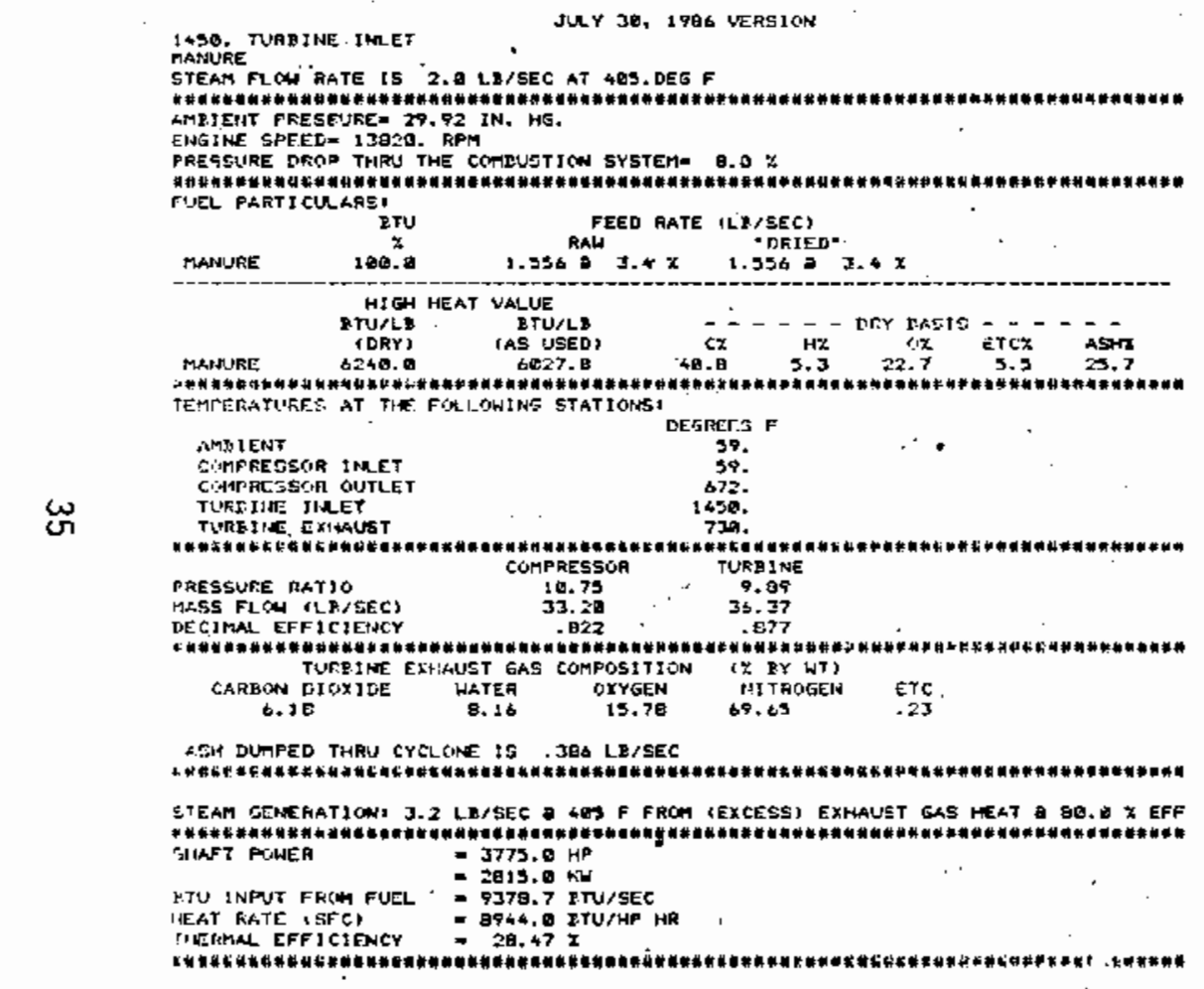

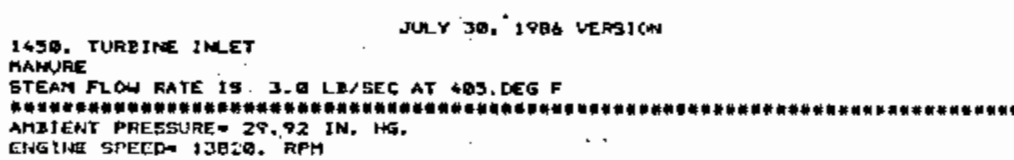

PRESEURE OFOP THMU THE COMBUSTION SYSTEM- B.-Z

FUEL PARTI ICULARS:

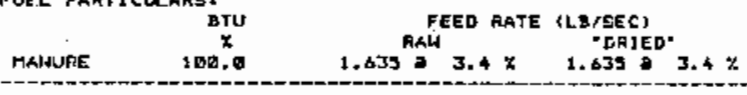

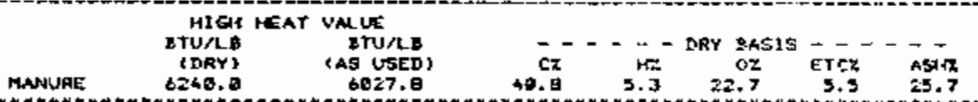

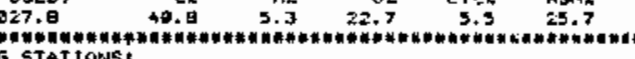

DEGREES $F$

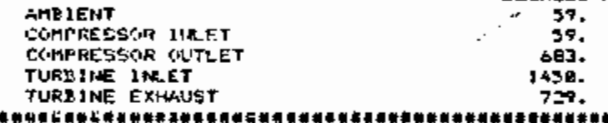

AUR2 INE EXH\&UST

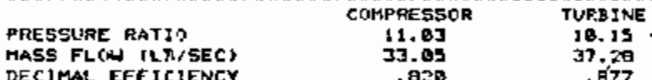

MH:

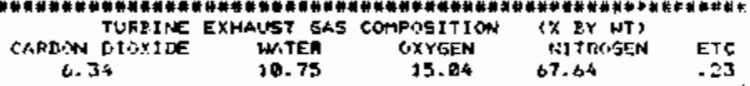

ASH DUMPCD TIRU CVCLCNE IS 406 LX/SEC

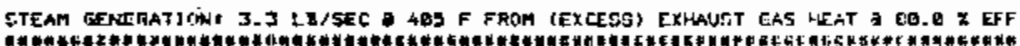
MUMANG SHAFT PQAEA $=4239.8 \mathrm{HP}$

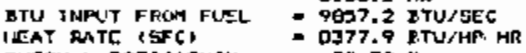

TIEFHAL EFFIEIENCY $=30.39 \mathrm{z}$

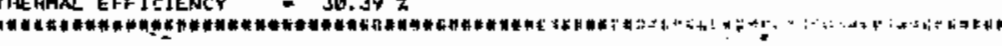


GENERUL/SRC (RUN GENRUN)/ OCTOBEA, 2966 VERSION

STEAM INUECT1ON 15 NOT UEED IN THIS BYSTEM.

HATER INUECTION IS MOT YSED IN THIS EYSTEY

ATBIENT PRESTURE= $Z 9.92$ IN, HG.

ENGINE GPEED- TJSZO. RPM

He COT

FUEL PARTI CUAARS!

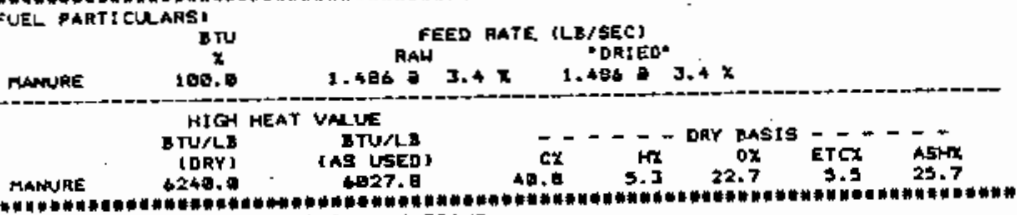

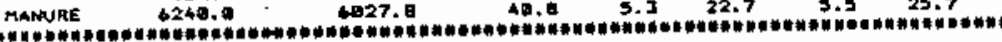

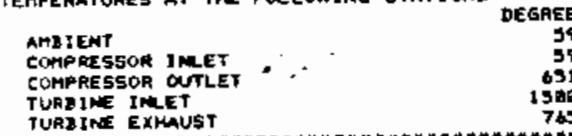

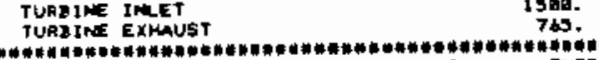

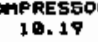

TUREINT:

PRESSURE RATIO

33.351340 .077

CLIMN EFFICIENGY

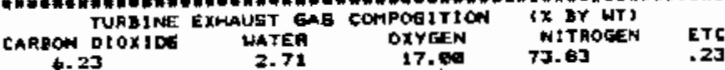

ASH DUMPED THRU CYCLONA IB . 349 LN/SEC

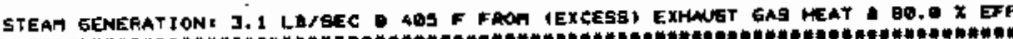

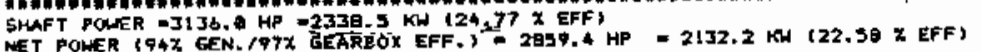
DTU INPUT FROM FLEL - B9SA.6 BTU/5EC SHAFT MEAT RATE (5FC) $=10279.6$ BTU/HP HR

GERERM /SRC "RWN GENAUN), OCTO2EF, 1996 VERSION

STEAM INUECTION IS ANT USED IN TH18 SVISTEM.

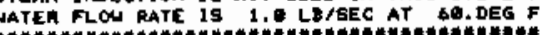

NMBIENT PRESSUAE= 29.92 IN, HG.

CAMENE GRE FUEL PARTICULARS:

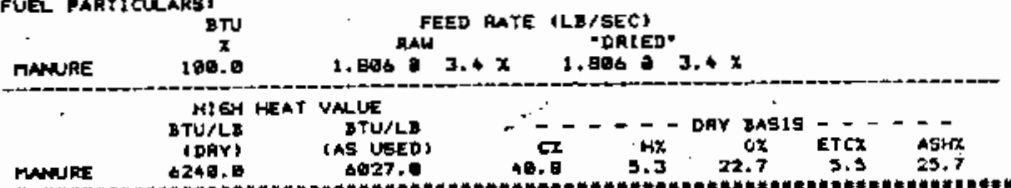

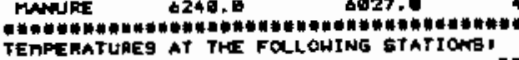

EEPERATLAES AT THE FQLLOHING STATIOMB' DEGREFS $F$

\section{NMRIEAT
COMPRESSOR INETT
COMPRESSOR OURET \\ TURRINE IR,ET \\ Tunatile ExHAUat}

ON

PRESEURE RAT:OO

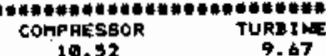

PASS FLO RAT TLOISEC

33.25

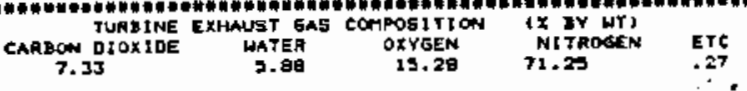

ASH DUMPED THAU CYCLONE IS 448 LG $19 E C$.

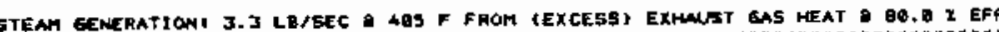

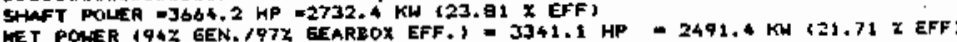
ITU INPUT FROA FUCL $=10683$. 6 BTW/SEC

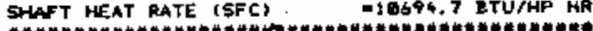


STEAT INJECTION IS NOT USED IN FHIO SYSTEM,

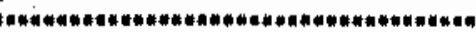
$29.921 \mathrm{~N}, \mathrm{HG}$

PRESSURE DROP THFU THE COMDUSTIOH SYSTEME $0.0 \times 12.7$ PSI

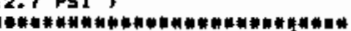
E. PARTICULARS:

MAMURE FEED RATE (LE/EEC)

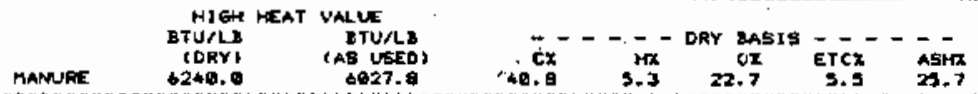

$14003.3 \quad 23.7 \quad 5.5 \quad 30.7$ TEMPEFATURES AT THE FOLLOHING STATI ONS

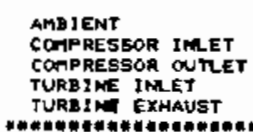

(a)

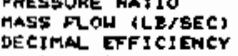

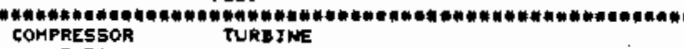

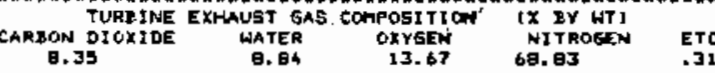

ASH DUMFEO THRU CYCLONE IS .527 LS/DEC

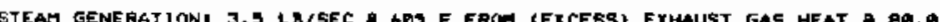

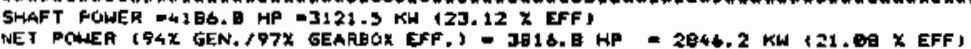

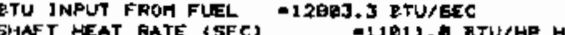

$\therefore$
GENERNL/SRE (PUN GEMRUN)' OCTORER, 19ES VERSIOW
13Q6. TURBINE IMLET

STEAY I NJECTIST IS NOT USED IN THIS SYSTET.

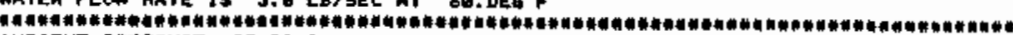
AME?ENT PAESSURE- 29.92 IN. HS.

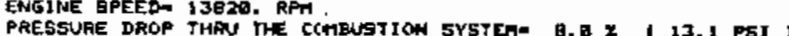

RE S FUEL PARTICUASS:

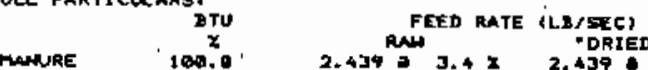

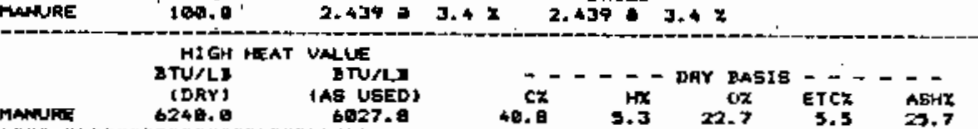

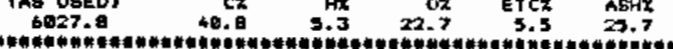
TEMPEPATUAES AT THE FOLLOHING STATIOASI AMEIENT DEGREES F

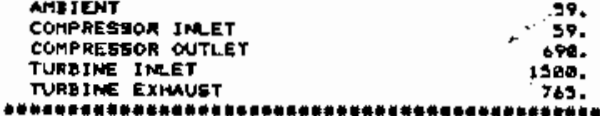

$\therefore$. 59.

76 :

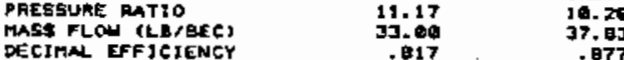

CARBCH TURA:ME EXHAUST GAS COMPOSIY1ON

CARBCH DIOXIDE WATER OXYGEM (ZITROED ETC

ASY DURPED THAO CYOiONE IS . BES LR/6EC

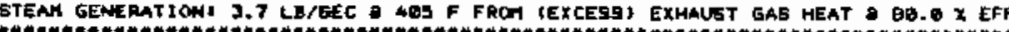
GhaFT POHER

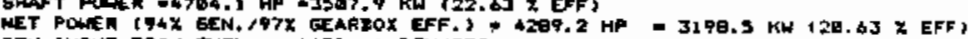
ETU IMPUT FROM FUEL $-14701 .+$ ETU/SEC

GHET HEAT RATE YSPCT, 


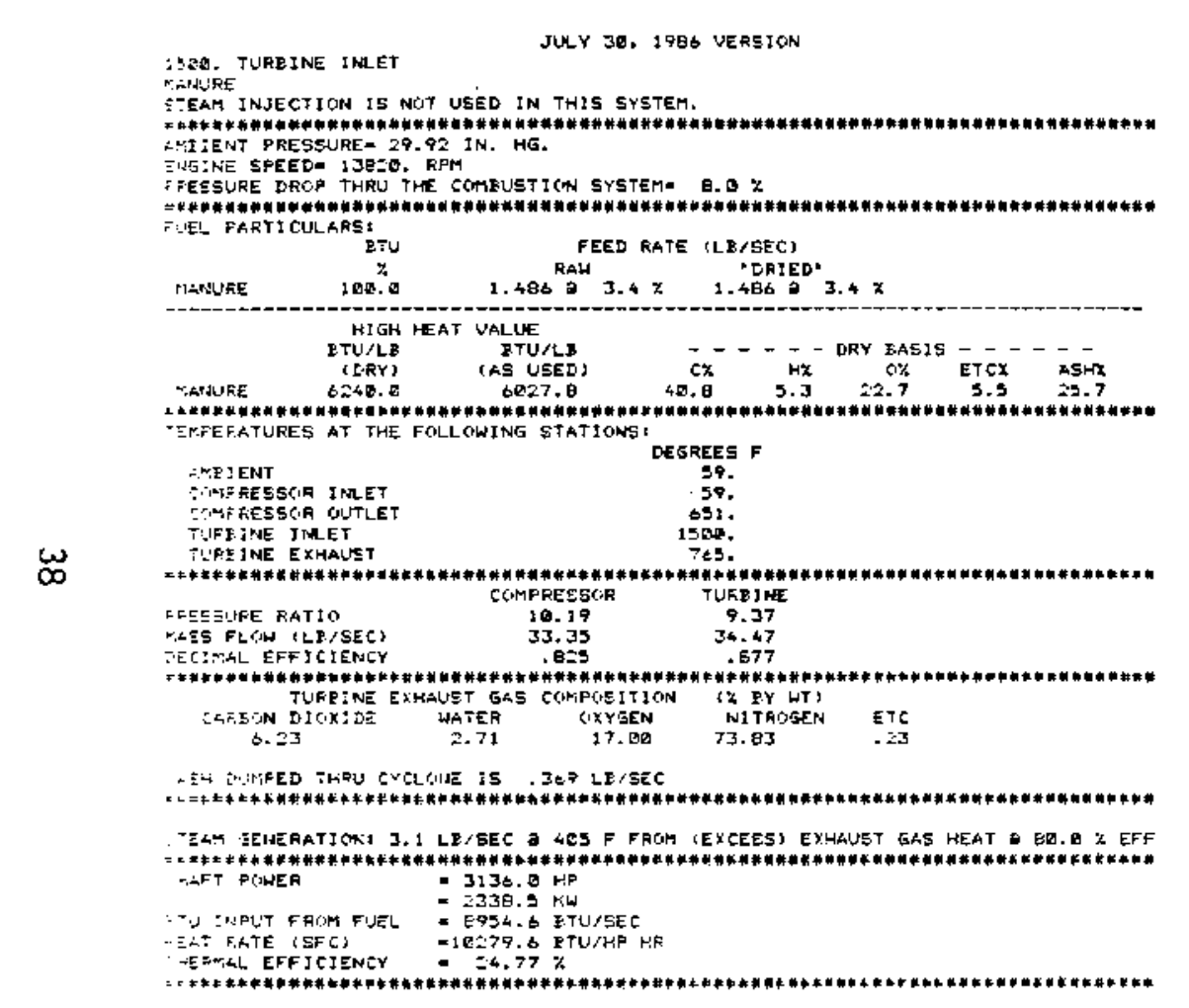




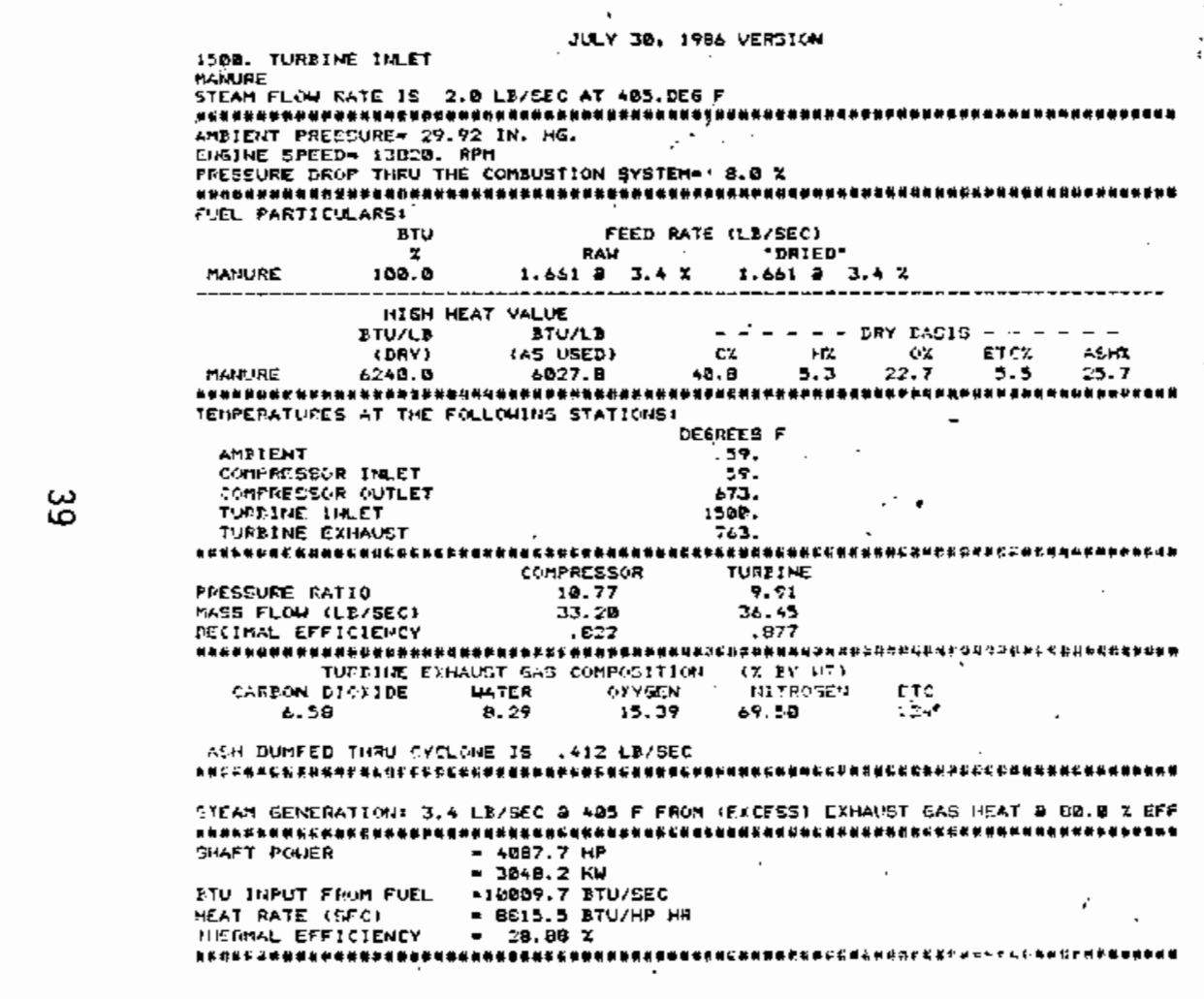

15E0. YURD 1NE INEST

JUYY 30. 1906 VERSION

STEAT FLCH RATE 19 3. D LX/SEC AY 405 . DEG F EMGINE SPEED $13 \mathrm{BZ}$.

PTESTEF DTOP THFS THE COMBUSTION SYSTEM- B. O $X$

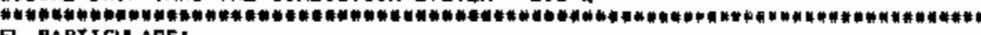

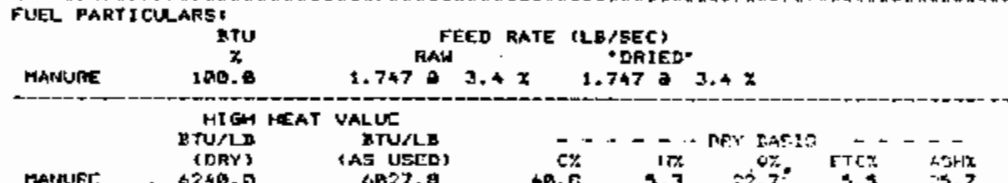

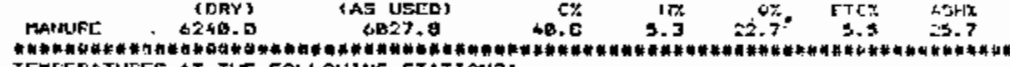
TEMTEFATUTES AT TIEE FOLLOWING STATIONSI DEGREES F

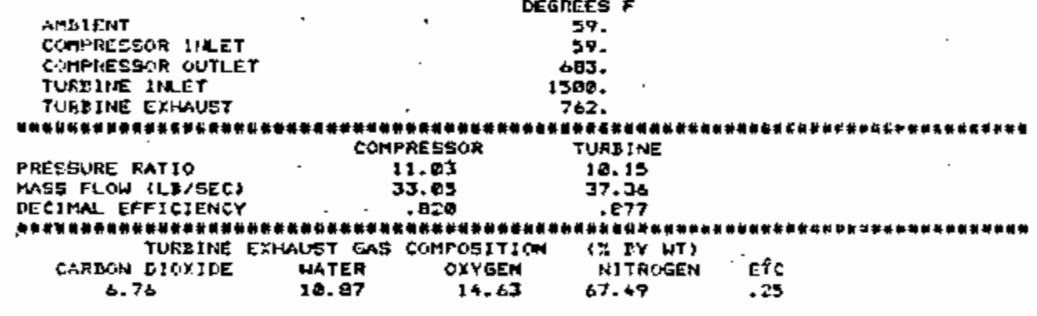

ASH DWMFED TIRU CYOCONE IS 434 LB/SSC

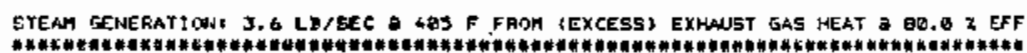
SIINTS POWER

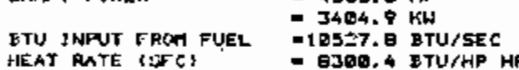
HIEAY PATE (SIFC)

TIRRMAL EFFICIENCY 
APPENDIX 5

BATTELLE-COLUMBUS REPORT

ON EMISSIONS MEASUREMENTS 
TOPICAL REPORT

on

MANURE-FIRED TURBINE EMISSIONS MEASUREMENTS

to

\section{PACIFIC NORTHWEST LABORATORIES}

Richland, Washington

April 27, 1987

by

Paul R. Hebb

8ATTELLE

Columbus Division

505 King Avenue

Columbus, $\cdot$ OH 43201-2693 
TOPICAL REPORT

on

MANURE-FIRED TURBINE EMISSIONS MEASUREMENTS

to

PACIFIC NORTHHEST LABORATORIES
Richland, Washyngton

by

Paul R. Webb

from

BATTELLE

Columbus Division

Apr11 27, 1987

\section{SUMMARY}

Particulate mass, particle size distribution, and gaseous emissions were measured from the manure combustor-turbine system at the Aerospace Research Corporation factlitty in Roanoke, Virginia, during the week of March 8, 1987. The facflity was operated with 48 percent propane and 52 percent manure during the measurements. Mr. Joseph Hamrick of Aerospace Research indicated that the combustor was operating at 132 ib per hour of manure which contained 22 percent motsture. Total calculated mass throughput of the turbine for manure was $6200 \mathrm{lb}$ per hour. Fuel heat input, based on $6240 \mathrm{Btu} / \mathrm{Jb}$ is $0.641 \times 10^{6} \mathrm{Btu} / \mathrm{hr}$. Particulate mass entering the turbine averaged $0.23 \mathrm{gr} / \mathrm{dscf}$ with 77.3 percent of the materlal being less than $1.3 \mu \mathrm{m} ; 100$ percent being less than $20.0 \mu \mathrm{m}$.

The mass mean diameter of the particles 15 less than 1 mlcron yet there is more than 5 ppm of particles greater than 5 micron. This result indicates excessive particulate loading by standard turbine guidelines. The particulate emissions also exceed EPA New Source Performance Standards. Chemical analys is of particulate samples indicate constituents which may cause corrosion of turbine blades. 
Gaseous emission measurements indtcated significantly high co levels $\left(6.52 \mathrm{lb} / 10^{6} \mathrm{Btu}\right)$. $\mathrm{NO}_{\mathrm{x}}$ and $\mathrm{SO}_{2}$ levels are relatively high; 0.53 and $1.06 \mathrm{ib} / 10^{6} \mathrm{Btu}$, respectively, as compared to EPA foss 11 fuel Itmits ${ }^{(1)}$ of 0.7 and $1.2 \mathrm{lb} / 10^{6} \mathrm{Btu}$, respectively.

\section{Background}

The gas turbine receives 1 ts energy from the combustion of feed lot manure. Durting these measurements propane was used to ald in the combustion process. The as-received manure which has about 50 percent moisture is air dried to about 22 percent molsture before being fired in the combustor. The compressor section of the turbine is initialiy driven by an internal combustion engine to develop sufficient combustion air pressure to operate the manure combustor. After sufficient temperature increase, the internal combustion engine is shut down and the system is self contained solely from the exhaust gases of the manure combustor. One cyclone is used to remove ash from the hot gas before it enters the turbine. The operating conditions, supplied by Mr. Joseph Hanrtck of Aerospace Research Corporation, are as follows:

$\begin{array}{ll}\text { Manure flow, } 52 \text { percent } & 132 \mathrm{lb} / \mathrm{hr}, 6240 \mathrm{Btu} / 1 \mathrm{~b} \\ \text { Propane, 48 percent } & 597,240 \mathrm{Btu} / \mathrm{hr} \\ \text { Manure ash content } & 25 \text { percent } \\ \text { Manure molsture content } & 22 \text { percent }\end{array}$

Sampling Equipment

The sampling equipment used for collecting ash for mass determination was a $47 \mathrm{~mm}$ stainless steel filter holder. The filter material was fiberglass which had been cut to fit the filter holder, desiccated, and weighed prior to collecting the ash sample. The filter holder was connected to 0.5 inch diameter stafnless steel tube 36 inches long, which was inserted into the stack elbow through a packing gland. The 0.5 inch diameter tube iniet was placed approximately 2 pipe diameters upstream of the discharge elbow and approximately 5 pipe dlameters downstraan of the cyclone discharge albow. Flgure i is a flow 


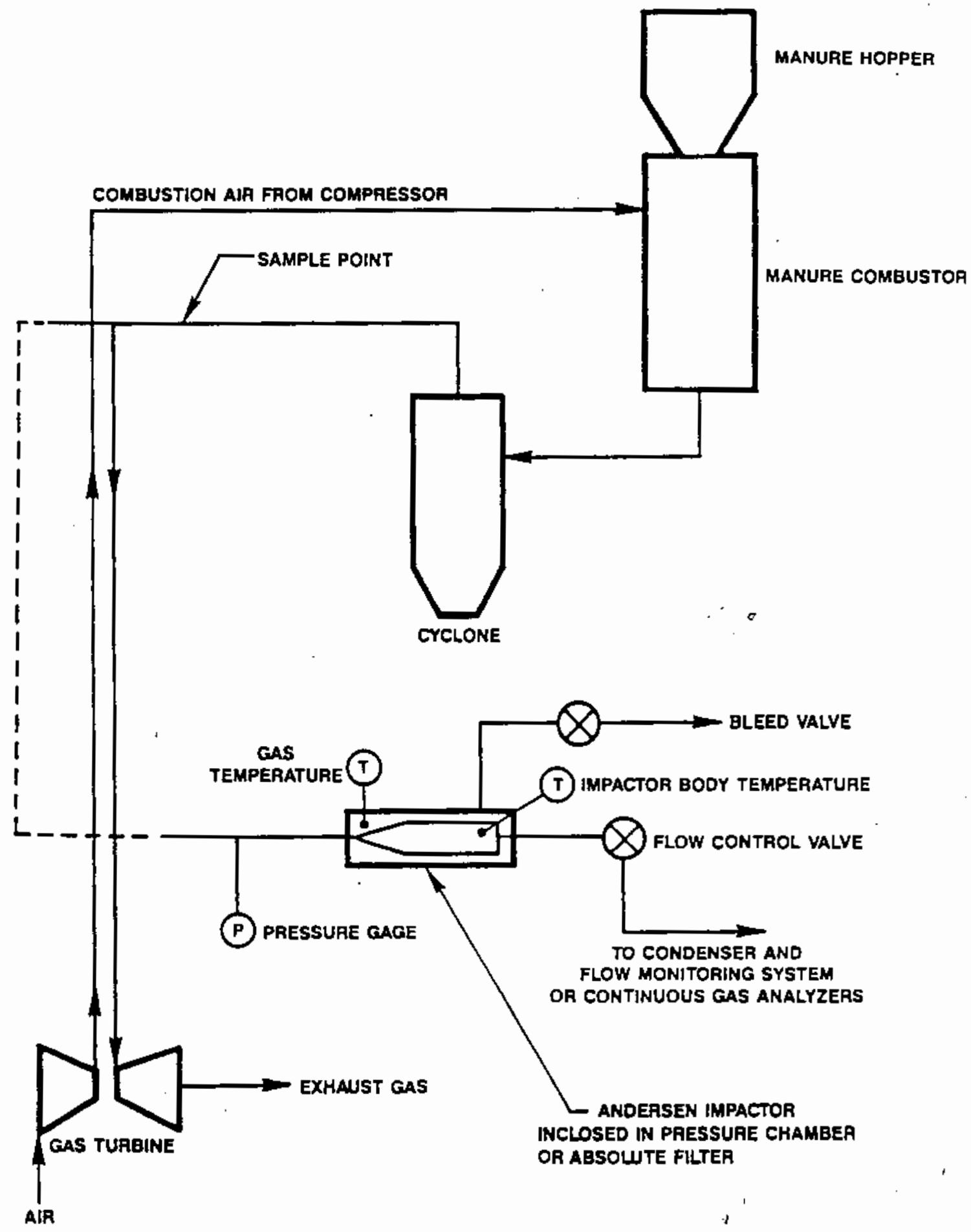

FIGURE 1 FLOW DIAGRAM OF MANURE COMBUSTOR AND GAS SAMPLING SYSTEM USED FOR PARTICULATE AND GASEOUS

EMISSION MEASUREMENTS 
diagram showing the sampling location and geometry of the manure combustor. The gas flow rate through the filter was controlled to maintain the filter temperature above the dew point of the water vapor. The gas was then passed through glass condensers at $32 \mathrm{~F}$ to remove the water vapor before passing through a dry gas meter for volume determination. The inlet and outlet temperature of the gas meter was monitored so that gas volumes could be corrected to standard conditions of $70 \mathrm{~F}$ and 29.92 inches of $\mathrm{Hg}$.

Sampling for particle size distribution incorporated an Andersen impactor which was placed in a pressure vessel. The $47 \mathrm{~mm}$ stainless steel filter holder was removed from the system and replaced with the Andersen impactor. The pressure vessel is equipped with a pressure gage, thermocouples, and valves. The combustion gases are allowed to vent to the atmosphere prior to initiating sampling. This allows the impactor to reach a temperature which is above the dew point of water vapor so that condensation, which could alter the size distribution measurement, will not occur during particle sampling. The impactor body temperature is measured independent of the gas temperature. The particles which enter the impactor are collected on pre-weighed filter media which are then desiccated and reweighed to determine the mass collected on each stage. There are seven stages of impaction plus a back-up filter. The size distribution measurement is a function of actual cubic feet per minute through the impactor which is a function of the impactor gas temperature and pressure.

The combustion gases were sampled to determine concentration of $\mathrm{NO}_{\mathrm{X}}$, THC, $\mathrm{SO}_{2}, \mathrm{O}_{2}, \mathrm{CO}_{2}$, and $\mathrm{CO}$ after removal of particulates. The following is a list of the analyzers used for these measurements:

Beckman Model 402

Beckman Model 955

Servomex Model OA580

Hortba Model PIR-2000

Hor1ba ModeI PIR-2000

Horiba Model PIR-2000
Total Hydrocarbons

Nitrogen Oxides

Oxygen

Carbon Monoxide

Carbon Dloxide

Sulfur Dioxide.

The instruments were calibrated with standard calibration gases before and after emission sampling. 
The system pressure was used to push the combustion gases through a $47 \mathrm{~mm}$ absolute filter to remove particulate. The gases then passed through a heated Telfon sample line which was controlled to $300 \mathrm{~F}$ for the determination of $\mathrm{NO}_{x}$ and THC. A needle valve was used to control the flow to maintain gas temperature to the Tefion sample line at 250-300 $F$. The gas was then passed through a $32 \mathrm{~F}$ 1ce bath condensor to remove molsture for the determination of $\mathrm{CO}, \mathrm{CO}_{2}, \mathrm{O}_{2}$, and $\mathrm{SO}_{2}$.

Gaseous Enissions

TABLE 1. COMBUSTION GAS COMPOSITION

\begin{tabular}{|c|c|c|c|}
\hline & ppm & $\mathrm{lb} / \mathrm{hr}$ & $1 \mathrm{~b} / 10^{6} \mathrm{Btu}$ \\
\hline THC & 110 & 0.38 & 0.59 \\
\hline \multirow[t]{2}{*}{$\mathrm{SO}_{2}$} & 50 & 0.68 & 1.06 \\
\hline & $175^{(a)}$ & 2.39 & 3.73 \\
\hline $\mathrm{CO}$ & 700 & 4.18 & 6.52 \\
\hline No $x$ & 35 & 0.34 & 0.53 \\
\hline \multirow[t]{2}{*}{$\mathrm{Cl}^{-}$} & $1^{(a)}$ & 0.01 & $0.02^{(b)}$ \\
\hline & $4^{(a)}$ & 0.04 & $0.08^{(c)}$ \\
\hline \multirow[t]{2}{*}{$\mathrm{NH}_{3}$} & $\left.1533^{a}\right)$ & 0.57 & 0.89 \\
\hline & $400^{(a)}$ & 1.49 & 2.32 \\
\hline
\end{tabular}

(a) Wet chemistry grab samples, (b) $\mathrm{pH}=3.0$, (c) $\mathrm{ph}=4.6$

In addition to the on-line continuous monitors, gaseous emissions were collected by wet chemistry for determination of the concentration of sulfur dioxide, ammonia, and chloride. Sulfur dioxide was collected in $100 \mathrm{ml}$ of 3 percent $\mathrm{H}_{2} \mathrm{O}_{2}$, and its concentration in solution determined by titration. Gaseous ammonta was collected in $0.02 \mathrm{~N}$ $\mathrm{H}_{2} \mathrm{SO}_{4}$, and its concentration determined by specific fon electrode. 
Gaseous chlorides were collected in distilled water, and their concentration determined by ion chromatography.

The gaseous emissions data presented in Table 1 indicate relatively high levels of carbon monoxide, sulfur dioxide and ammonia. The carbon monoxide can probably be attrfbuted to poor combustion. The gaseous ammonia in combination with gaseous chloride and/or sulfur dioxide could contribute to the corrosion of turbine blades:

\section{Particulate Emissions}

Particulate emissions as shown in Table 2 ranged from 0.20 gr/dscf to $0.29 \mathrm{gr} /$ dscf. The particle size data are shown in Table 3 . As indicated, 77.3 percent of the particle mass is less than $1.3 \mu \mathrm{m}$. The rule-of-thumb guide-lines of less than 5 ppm of particles greater than 5 $\mu m$ for turbine operation is not being met. Based on an average of 443 ppm, 10 percent of the material or approximately 44 ppm is greater than 5 $\mu \mathrm{m}$.

\section{Analysis of Particulate Samples}

The particulates collected during sampling were analyzed for selected water-soluble anions and cations. The particulate sample used for water-soluble anions was collected on $3 / 13 / 87$ while the sample used for cation analyses was collected on 3/15/87. The results of these analysis are given in Table 4.

The results suggest that the particulate material contained primarily potassium chloride and potassium sulfate with lesser amounts of sodium chloride and sodium sulfate. The presence of fluoride and phosphate were expected from manure and they probably existed in the particulate as salts of potassium and sodium. The quantities of calcium and iron were judged to be negligible and were assumed to exist as salts of the anjons. The presence of other metals in trace quantitles cannot be ruled out. Of the major constituents, 43 percent by weight was due to 
TABLE 2. SAMPLE DATA

\begin{tabular}{|c|c|c|c|c|c|c|}
\hline & \multicolumn{6}{|c|}{ Date } \\
\hline & $3-13-87$ & $3-13-87$ & $3-15-87$ & $3-15-87$ & $3-15-87$ & $3-15-87$ \\
\hline Run No. & $1(a)$ & 2 & $3(b)$ & 4 & 5 & 6 \\
\hline Clock Time & $1253-1258$ & $1717-1727$ & $1050-1100$ & $1120-1130$ & $1220-1223$ & $1230-1240$ \\
\hline Sample Time, min. & 5 & 10 & 10 & 10 & 3 & 10 \\
\hline Gas Meter Temp., F & 59 & 56 & 53 & 53 & 53 & 69 \\
\hline Bar Press, in. Hg & 29.12 & 29.12 & 29.06 & 29.06 & 29.06 & 29.06 \\
\hline Condensa te, grams & 2.8 & 12.5 & 10.5 & 11.0 & 7.0 & 9.0 \\
\hline Sample Vol., dscf & 1.97 & 5.22 & 3.42 & 4.12 & 1.70 & 3.82 \\
\hline Stack Moisture, percent & 6.32 & 10.15 & 12.8 & 11.2 & 16.26 & 10.05 \\
\hline Stack Pressure, psig & 8.2 & 9.0 & 8.9 & 9.9 & 9.9 & 9.9 \\
\hline $\begin{array}{l}\text { Total Particulate Mass } \\
\text { Collected, mg }\end{array}$ & - & $69.8(\mathrm{e})$ & 45.0 & $77.6(f)$ & 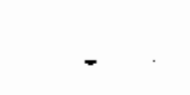 & - \\
\hline \multicolumn{7}{|l|}{ Particulate Conc. } \\
\hline $\mathrm{gr} / \mathrm{dsef}$ & - & 0.21 & 0.20 & 0.29 & - & - \\
\hline $\mathrm{ppm}$ & - & 392 & 385 & 553 & - & - \\
\hline lbs per nour $(c)$ & - & 2.43 & 2.39 & -3.43 & - & - \\
\hline lbs per $10^{6} \mathrm{Btu}(\mathrm{d})$ & - & 3.79 & 3.73 & 5.35 & - & - \\
\hline
\end{tabular}

(a) Propane fuel only

(b) Anderson size distribution

(c) Based on $6200 \mathrm{Jb} / \mathrm{hr}$ total mass

(d) Manure only; at $0.641 \times 10^{6} \mathrm{Btu} / \mathrm{hr}$

(e) Analyzed for Anions

(f) Analyzed for Cations. 
TABLE 3. SIZE DISTRIBUTION(a)

\begin{tabular}{ccccc}
\hline \hline Stage & Sampling condition: & 0.36 acfm, $300 \mathrm{~F}, 8.9 \mathrm{psig}$ \\
\hline 0 & Mass, mg & $\begin{array}{c}\text { Percent } \\
\text { of Total }\end{array}$ & Cum percent & Partiçe size, um \\
1 & 1.3 & 2.9 & 100.0 & 20.0 \\
2 & 0.9 & 2.0 & 97.0 & 10.3 \\
3 & 0.7 & 1.6 & 95.0 & 8.4 \\
4 & 1.3 & 2.9 & 93.4 & 5.8 \\
5 & 1.9 & 4.2 & 90.6 & 1.8 \\
6 & 4.1 & 9.1 & 86.4 & 1.3 \\
7 & 8.2 & 18.2 & 77.3 & 0.8 \\
Filter & 4.5 & 10.0 & 59.1 & 0 \\
- Tota] & 22.1 & 49.1 & & \\
\hline \hline
\end{tabular}

(a) Run No. 3 
TABLE 4. ANALYSIS OF PARTICULATE SAMPLES Percent by Weight

\begin{tabular}{|c|c|c|c|c|c|c|c|c|c|}
\hline Sample Date & $\mathrm{Na}^{+}$ & $k^{+}$ & $\mathrm{Ca}$ & Fe & $\mathrm{Cl}^{-}$ & $\mathrm{SO}_{4}-2$ & $\mathrm{PO}_{4}-3$ & $\mathrm{~F}^{-}$ & pH \\
\hline $3 / 15 / 87$ & 4.4 & 40.1 & 0.147 & 0.111 & - & - & - & - & - \\
\hline $3 / 13 / 87$ & - & - & - & - & 31.3 & 29.1 & 0.30 & 0.27 & 5.2 \\
\hline
\end{tabular}

the cations $\mathrm{Na}^{+}$and $\mathrm{K}^{+}$while 60 percent was attributed to the anions $\mathrm{Cl}^{-}$ and $\mathrm{SO}_{4}{ }^{-2}$ for a sum total of 103 percent. The total value of 103 percent was judged to be reasonable since the analyses were performed on two different samples. The fact.that the water solution of the anion sample had a pH of 5.2 suggests that elther sulfate or phosphate wás present as the acid salt and that oxides or carbonate of sodfum or potassium were absent or present in extremely small amounts. The low pH and the presence of chloride in the water impingers support this premise (See Table 1).

\section{Remarks}

The consequences of the presence of a mixture of potassium and sodium sulfate and chloride salts with lesser amounts of calctum, fron, fluoride and phosphate salts is the potential for high temperature corrosion of steels. The effects of combinations of chloride and sulfate salts of the alkall metals on the corrosion of steels have been investigated over a broad range of temperatures. $(2-7)$

\section{Conclustons}

The particulate mass loading is not acceptable by standaro guldelines for turbinj operation. Although the mass mean diameter of the particles is less than $0.8 \mathrm{um}$, there is still more than $5 \mathrm{ppm}$ of the 
particles greater than $5.0 \mu \mathrm{m}$. Although there are no EPA regulations regarding particulate emissions levels for manure combustion, it can be assumed that particulate emissions are excessive when compared to regulations for fossil fuel combustion, t.e., 0.1 lb per $10^{6} \mathrm{Btu}$. The potential exists for turbine blade corrosion/erosion/deposition due to relatively high levels of potassium and sodium sulfate and chloride salts in the particulates. The wet chemistry analysis for $\mathrm{SO}_{2}$ indicates that emission levels exceed Federal EPA regulations; on-line continuous monitoring for $\mathrm{SO}_{2}$, although less than federal EPA regulations, is still considered excessive.

\section{Recormendations}

Due to the fact that the fuel has 25 percent ash, it will be necessary to incorporate additional control devices for acceptable particulate enissions. The constituents of the ash which may be harmful to turbine blades must be addressed, especially in view of the relatively high mass loading.

\section{References}

1. Sub Part D, Standard of Perfomance of New Stationary Sources (40 CFR 60), Revised July 1, 1984.

2. Krause, H. H., Vaughan, D. A., and Miller, P. O., "Corrosion and Oeposits from Combustion of Solld Wastes," Journal of Engineering for Power, Trans. ASME, Series A, Vol. 95, No. 1, Jan. 1973, pp 4552 .

3. Krause, H. H., Vaughan, D. A., and Miller, P. D., "Corrosion and Deposfts from Combustion of Solld Waste, Part 2-Chloride Effects on Boller Tube and Scrubber Metals," Journal of Engtneering for Power, Trans., ASME, Series A, Vol. 96, No. 3, July 1974, pp 216-222.

4. Krause, H. H., Vaughan, D. A., and Boyd, H. K., "Corrosion and Deposits from Combustion of Solid Waste, Part 3-Effects of Sulfur on Boiler Tube Metals," Journal of Engineering for Power, Trans," ASME, Series A, Yol. 97, No. 3, July 1975, po. 448-452. 
5. Krause, H. H., Vaughan, D. A., and Boyd, H. K., "Corrosion and Deposits from Combustion of Solid Haste, Part 4-Combined Firing of Refuse and Coal," Journal of Engineering for Power, Trans., ASME, Sertes A, Yo1. 98, No. 3, July 1976, PD. 369-374.

6. Ross, T. K., "The Distributton of Sulfur in Corrosion Products Formed by Sulfur Oxides on Mild Steel," Corrosion Science, Yol. 5, 1965, pp. 327-329.

7. Brown, M. K., DeLong, W. B., and Auld, J. R., "Corrosion by Chlorine and by Hydrogen Chloride at high Temperatures," Journal of Industrial and Engineering Chemistry, Yol. 39, 1947, pp. 839-844. 


\section{DISTRIBUT ION}

No. of

Copies

\section{OFFSITE}

10 DOE/Office of Scientific and Technical Information

H. Abernethy

Abernethy Wood Construction

6016 Brookvale Lane

Suite 109

Knoxville, TN 37919

M. J. Antal, Jr.

Dept. of Mechanical Engineering

University of Hawai $i$

2540 Dole Street

Honolulu, HI 96822

W. Ayres

Pyrotech, Inc.

8016 Stateline

Suite 101

Leawood, KS 66208

P. Badger

Biomass Fuels Program

Tennessee Valley Authority

Muscle Shoals, AL 35660

D. Bancroft

Council of Great Lakes Governors

122 West Washington Ave., \#801A

Madison, WI 53703

V. J. Flanigan

University of Missouri-Rolla

223 Engineering Research Lab. Rolla, MO 65401
No. of

Copies
P. Fox

Pacific Northwest and Alaska Bioenergy Program

Bonneville Power Administration Routing, EPG

U.S. Department of Energy

P.0. Box 3261

Portland, OR 97208

4 S. Friedrich

Biofuels and Municipal Waste

Technology Division

U.S. Department of Energy

Forrestal Building (CE-341)

1000 Independence Avenue

Washington, D.C. 20585

R. Gyllenborg

Southwest Regional Biomass

Energy Program

Western Area Power Authority

P.0. Box 3402

Golden, Co 80401

B. Goodman

Solar Energy Research Institute 1617 Cole Blvd.

Golden, CO 80401

10 J. T. Hamrick

Aerospace Research Corporation

5454 Jae Valley Road

Roanoke, VA 24014

J. E. Helt

Argonne National Laboratory

Building 205

$9700 \mathrm{~S}$. Cass Avenue

Argonne, IL 60439 
No. of

Copies

W. D. Hunter

Energy Technology Department

Weyerhaeuser Company

WTC-1B-30

Tacoma, WA 98477

R. J. Loose

Office of Renewable Technology

U.S. Department of Energy

Forrestal Building

1000 Independence Avenue

Washington, D.C. 20585

P. D. Mathusa

New York State Energy Research and Development Authority

2 Rockefeller Plaza

Albany, NY 12223

T. R. Miles, $\mathrm{Sr}$

Consulting Design Engineers

5475 S.W. Arrowwood Lane

Portland, OR 97225

R. O'Connell

Northeast Regional Biomass

Energy Program

Coalition of Northeastern Governors

406 N. Capital St., N.W. Suite 38

Washington, D.C. 20001

M. Paisley

Battelle-Columbus Laboratories 505 King Avenue

Columbus, $\mathrm{OH} 43201$

H. Pattison

Southwest BioEnergy, Inc.

Star Route, Box 58

Clovis, NM 88101
No. of

Copies

N. F. Rekos

Morgantown Energy Technology

Center

U.S. Department of Energy

P. 0. BoX 880, MS E03

Morgantown, WV 26507-0880

G. Simons

California Energy Commission

1516 - 9th Street, MS-43

Sacramento, CA 95814

F. Sparber

Independent Solar Research

Route 1, Box 192-A

Belin, NM 87002

P. Takahashi

Hawaif Natural Energy Institute

2540 Dole Street

Holmes 240G

Honolulu, HI 96822

D. K. Walter

Biofuels and Municipal Waste Technology Division

U.S. Department of Energy

Forrestal Building (CE-341)

1000 Independence Avenue

Washington, D.C. 20585

E. I. Wan

Science Applications

International Corporation

1710 Goodridge Drive

McLean, VA 22102

R. Williams/E. Larson

School of Engineering/Applied

Science

Center for Energy and

Environmental Studies

Engineering Quadrangle

Princeton University

Princeton, NJ 08544 
No. of

Copies

ONSITE

DOE Richland

Operations office

J. J. Sutey/D. R. Segna

16 Pacific Northwest

Laboratory

M. A. Gerber

G. F. Schiefelbein (6)

L. J. Sealock

D. J. Stevens

Publishing Coordination (2)

Technical Report Files (5) 


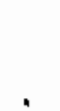

' 